\title{
A Histological Study on the Effect of Dextrose Prolotherapy on Skeletal Muscle Injury in Adult Male Albino Rats
}

\author{
Original \\ Article \\ Eman Diaa Eldeen, Azza Salah El Din Soliman, Rania Ahmed Salah El Din, \\ George Fayek Barsoum Hanna, Shereen Adel Saad
}

Department of Anatomy, Faculty of Medicine, Ain Shams University, Egypt

\begin{abstract}
Background: Skeletal muscle injuries are one of the most common injuries in sport medicine. Many injection protocols have been proposed for the treatment as corticosteroid injection. Recently prolotherapy appears to have a safety profile comparable with other injection procedures.

Aim of the Work: Was to determine the efficacy of dextrose prolotherapy in treatment of skeletal muscle injury in adult male albino rats.

Material and Methods: Sixty three adult male albino rats were used in the study. They were divided into control (group I). Group II was divided into sham operated group (group IIA) and muscle injury group (group IIB) and group III was divided into lidocaine injected group (group IIIA) and muscle injury treated with dextrose prolotherapy group (group IIIB). Muscle specimens were taken at 5,12 and 28 days and processed for light microscope

Results: Examination of Group IIB1 (5 days) showed intense infiltration of mononucleated inflammatory cells intermingling with dispersed myoblasts and macrophages. Group IIB2 (12 days) showed regenerating myotubes intermingling with mononuclear inflammatory infiltrate and macrophages. Group IIB3 (28 days) showed some muscle fibers with peripherally elongated nuclei while others showed centrally vesicular ones. Examination of group IIIB1 (5 day treated) showed longitudinal regenerating myofibers with multiple rows of internal vesiculated nuclei. Group IIIB2 (12 days treated) showed newly formed myofibers with incomplete striations together with well developed newly formed striated longitudinal muscle bundles with peripheral flattened nuclei , group IIIB3 (28 days treated) showed cross striated muscle fibers with the appearance of elongated vesicular nuclei.

Conclusion: Dextrose prolotherapy was effective in soft tissue healing as it accelerated myoblast proliferation and differentiation.
\end{abstract}

Received: 18 September 2020, Accepted: 18 November 2020

Key Words: Dextrose, injury, muscle, prolotherapy, skeletal,

Corresponding Author: Shereen Adel Saad, PhD, Department of Anatomy, Faculty of Medicine, Ain Shams University, Egypt, Tel.: +202 26713486, E-mail: shereenanatomy77@yahoo.com

ISSN: 1110-0559, Vol. 44, No.3

\section{INTRODUCTION}

Skeletal muscle provides a major site for energy storage in the body ${ }^{[1]}$. Muscle injuries are one of the most common injuries in sport medicine, their frequency varies from $10 \%$ to $55 \%$ of all injuries ${ }^{[2]}$.

Treatment of the injuries is based on conservative measures as rest, stretching, strengthening and nonsteroidal anti-inflammatory medications ${ }^{[3]}$. In addition, many injection protocols have been proposed for the treatment of muscle lesions as corticosteroid injection ${ }^{[4]}$. However recently prolotherapy injections appears to have a safety profile comparable with other injection procedures $^{[5]}$.

Proliferative therapy (prolotherapy or regenerative injection therapy) is a non-surgical technique that introduce locally irritant substances (proliferant) to the site of painful and degenerated tendons, joints, ligaments and muscles. This prolotherapy allows natural healing process of the body by initiating a local inflammatory cascade that trigger the release of growth factors as platelet derived growth factors (PDGF), fibroblast growth factor (FGF) that induce myoblasts proliferation and fusion and insulin growth factor (IGF) that induce myoblast proliferation, also it induces fibroblast proliferation and deposition of less dense collagen type III $^{[6-8]}$.

The most common used agent is hyperosmolar dextrose usually in a concentration of $25 \%$ mixed with saline. Hypertonic dextrose solutions act by dehydrating cells at the injection site leading to local tissue trauma, which attracts granulocytes and macrophages and promotes healing. Also, increases infiltration of leucocytes and interleukin-1 beta which acts as chemical building blocks so improves strength, mass and thickness of soft tissues ${ }^{[7,9]}$.

So the aim of the present work is to determine the efficacy of dextrose prolotherapy in treatment of skeletal muscle injury in adult male albino rats.

\section{MATERIAL AND METHODS}

Sixty three adult male albino rats of average weight (180-250 grams), (4 -6 months) were used in present the study. Animals were purchased \& were housed in the 
experimental unit-Medical Research Center, Faculty of Medicine, Ain Shams University.

\section{Study procedures and interventions}

Rats were assigned into three groups:

\section{Group I control group (9 rats)}

The rats were left without any intervention.

\section{Group II (21 rats)}

It was divided into

\section{Sham operated group IIA (left hindlimb)}

The left hindlimbs of the rats were subjected to skin incision without injury to gastrocnemius muscle followed by suturing of the wound.

\section{Muscle injury group IIB (right hindlimb)}

The right hindlimbs of the rats were subjected to skin incision followed by a transverse cut injury across the midbelly of the gastrocnemius muscle.

Then, group IIA and IIB were further subdivided into 3 subgroups (7 rats/subgroup):

- $\quad$ Subgroup IIA1\& IIB1: the muscle specimen was taken on day 5 post-wounding ${ }^{[10]}$.

- Subgroup IIA2 \& IIB2: the muscle specimen was taken on day 12 post-wounding ${ }^{[10]}$.

- $\quad$ Subgroup IIA3 \& IIB3: the muscle specimen was taken on day 28 post-wounding ${ }^{[11,12]}$.

\section{Group III (33 rats)}

It was divided into

\section{Lidocaine injected group IIIA (left hindlimb)}

The left hindlimb of the rats were subjected to skin incision without injury of gastrocnemius. The left hindlimb were injected with $0.3 \mathrm{ml}$ of $1 \%$ lidocaine. The animals received 6 injections of $0.3 \mathrm{ml}$ of $1 \%$ lidocaine at 5 day intervals starting from day 0 to day 25 in the left gastrocnemius muscle followed by suturing of the wound.

\section{Muscle Injury treated with dextrose Prolotherapy group IIIB (right hindlimb)}

The right hindlimb of the rats were subjected to skin incision followed by a transverse cut injury across the mid-belly of the gastrocnemius muscle, then the injured site was injected by $0.1 \mathrm{ml}$ of dextrose prolotherapy of mixture of $0.1 \mathrm{ml}$ of $12.5 \%$ dextrose and $0.3 \mathrm{ml}$ of $1 \%$ lidocaine. The animals received 6 injections of dextrose prolotherapy at 5 days interval starting from day 0 to day 25 followed by suturing of the wound ${ }^{[10,13]}$.

Then, group IIIA and IIIB were further subdivided into 3 subgroups (11 rats/subgroup)

- Subgroup IIIA1 \& IIIB1: the muscle specimen was taken on day 5 post-wounding ${ }^{[10]}$.
- Subgroup IIIA2 \& IIIB2: the muscle specimen was taken on day 12 post-wounding ${ }^{[10]}$.

- Subgroup IIIA3 \& IIIB3: the muscle specimen was taken on day 28 post-wounding ${ }^{[11,13]}$.

\section{Preparation of muscle injury model}

Rats were anesthetized by diethyl ether and the skin of the right leg was incised and a transverse cut injury 5 $\mathrm{mm}$ long and $5 \mathrm{~mm}$ deep was made across the mid-belly of the gastrocnemius muscle of right hind limb. A suture was placed at either end of the cut for further identification of the lesion site, then the overlying skin was closed ${ }^{[10]}$.

\section{Collection of samples}

At the determined time points (day 5, day 12 and day 28) of the present experiment, rats were sacrified and the entire muscle specimen was obtained. Half of the specimens were fixed in $10 \%$ formalin and processed for preparation of paraffin blocks. Paraffin sections were stained with Hx\&E and Masson's Trichrome together with immunohistochemical stains. The other half of the specimens were fixed in glutaraldehyde for preparation of semi-thin sections. All stained sections were examined by light microscopy ${ }^{[10-12]}$.

\section{Tissue processing for light microscope}

The muscle injury specimens were fixed in $10 \%$ neutral formalin in water for 48 hours, dehydrated in ascending grades of ethanol and cleared in xylol to prepare paraffin blocks. Sections of 5 micrometer thickness were obtained and subjected to staining by Hx\&E and Masson`s Trichrome stains ${ }^{[14]}$.

\section{Tissue processing for semithin sections}

The muscle injury specimens were immediately cut into small blocks $(1 \mathrm{~mm} 3)$ and fixed in $2.5 \%$ gluteraldehyde for 24 hours. Then washed 3 times in phosphate buffer (ph 7.4), post fixed in 1\% osmium tetroxide for 2 hours, dehydrated in ascending grades of ethyl alcohol, cleared in propylene oxide for 20 minutes at room temperature. Infiltration was then done by using equal parts of propylene oxide and epon 812 for overnight. Finally, the specimens were embedded in gelatin capsules filled with fresh epon. The capsules were kept at $60 \mathrm{C}$ for 48 hours to allow polymerization. Semithin sections were cut (1micrometer) thickness. Sections were stained with $1 \%$ toluidine blue dissolved in $1 \%$ borax for approximately 30 seconds and examined under the light microscope ${ }^{[15]}$.

\section{Immunohistochemistry}

\section{Desmin monoclonal mouse antibody}

Paraffin sections were dewaxed and rehydrated. Slides were incubated in $0.1 \%$ sodium azide containing 3\% hydrogen peroxide, then treated with 5\% normal goat serum in phosphate buffered saline (PBS) for $15 \mathrm{~min}$, to block non-specific binding. The primary antibody was desmin monoclonal mouse antibody (clone 33, Biogenex, 
San Ramon, CA), at a dilution of 1:160. The primary antibodies were applied to sections in $1 \%$ BSA, $0.05 \mathrm{M}$ Tris-HCI, pH 7.4; the slides were then incubated for 60 min in a moist chamber at $25^{\circ} \mathrm{C}$. After three 5 min washes in PBS, the slides were treated with secondary biotinylated goat anti-mouse antibody (Biogenex, San Ramon, CA), at a dilution of 1:50 for $30 \mathrm{~min}$. After three $5 \mathrm{~min}$ washes in PBS, peroxidase-conjugated streptavidin (Biogenex, San Ramon, CA) diluted at 1:50 was applied for $45 \mathrm{~min}$. In order to check for peroxidase activity, the sections were treated for 10 min with $0.05 \%$ freshly made and filtered solution of 3-3'-diaminobenzidine tetrahydrochloride (DAB) (Sigma Chemical Company, St. Louis, Missouri) in $10 \mathrm{ml}$ of $0.05 \mathrm{M}$ Tris-Hcl, $\mathrm{pH} 7.6$ to which $0.03 \%$ hydrogen peroxide was added. Positive staining was recognized as a brown color ${ }^{[16]}$

\section{Histomorphometric and statistical studies}

NIH "Image J" computer image analysis software version $1.40 \mathrm{~g}$ was used to count the number of regenerating cells, macrophages and area percentage of collagen fibers deposition per microscopic field.

For each of the previous entries, measurements were taken from six microscopic fields per slide, six slides per rat and six rats per group.

Counting the number of regenerating cells and macrophages per microscopic field were done using the (X40) objective lens, while, area percent of collagen fibers was done using the (X10) objective lens.

Calibration of the software was done for each microscopic magnification in order to translate pixels into micrometers. This was done with the aid of a stage micrometer.

For measurement of area percentage per microscopic field used for quantitation of collagen fibers, images were splitted into RGB stacks the the red stacks was chosen and adjusted to grey scale threshold to mark the stained areas of positive immunoreactivity with a red-colored binary mask, then the percent of these areas in relation to the microscopic field was calculated.

\section{Statistical analysis}

Statistical analysis was done using the SPSS software (Statistical Package for Social Studies- version 13.0). One-way analysis of variance (ANOVA) was employed to compare means in different groups with each other. Bonferroni Post Hoc test was used to detect significance between every two individual groups.

The significance of the data was determined by the probability $(P$. value). $P>0.05$ was considered non-significant. $P \leq 0.05$ was considered significant and $P \leq 0.001$ was considered highly significant ${ }^{[17]}$. Data were represented in tables and histograms, prepared by using MS Excel 2013.

\section{RESULTS}

Control group I, sham operated group IIB (B1, B2\&B3) and lidocaine injected group IIIB (B1, B2\&B3)

Examination of paraffin sections and semithin sections of gastrocnemius muscle of the control groups, either sham operated or lidocaine injected or control group without intervention, showed no differences with similar histological findings.

Examination of Hx\&E sections obtained from control group (I) , sham operated group IIB (B1,B2\&B3) and lidocaine injected group IIIB (B1,B2\&B3) revealed the longitudinal section of rat's gastrocnemius muscle appeared as cylindrical elongated muscle fibers arranged in parallel pattern with peripherally situated flattened nuclei. Moreover, some muscle fibers showed oval elongated nuclei (Figure 1). It revealed also bizzare shaped macrophages with abundant cytoplasm and large nuclei together with spindle shaped fibroblasts having flattened nuclei among delicate connective tissue surrounding the muscle fibers (Figure 2). Furthermore, Semithin sections showed the cross striations of muscle fibers that are formed of alternating light and dark bands together with peripherally situated flattened nuclei with prominent nucleoli within muscle fibers.Each muscle fiber is enveloped by fine connective tissue sheath called endomysium with spindle shaped fibroblast (Figure 3).

Examination of $\mathrm{Hx} \& \mathrm{E}$ sections obtained from subgroup IIB1 (5day untreated muscle injury group) revealed the injured area with intense infiltration of mononucleated inflammatory cells among granulation tissue intermingling with immature slightly differentiated myoblasts having vesicular nuclei and prominent nucleoli together with congested blood vessels (Figure 4). The widened intermuscular space showed bizzare shaped macrophages with abundant cytoplasm and large nuclei together with spindle shaped fibroblasts having flattened oval nuclei (Figure 5). Same findings were found in semithin sections. However, Hx\&E sections obtained from subgroup IIIB1 (5 day treated muscle injury group) demonstrated longitudinal regenerating myofibers with multiple rows of internal vesiculated nuclei and prominent nucleoli as we go away from the injured site, some areas showed dispersed vesicular nuclei of myoblastic cells (Figure 6). Semithin sections revealed bizzare shaped macrophages having abundant cytoplasm with large nuclei and prominent nucleoli intermingling with bundles of collagen fibers within the injured site (Figure 7).

Examination of Hx \& E sections obtained from subgroup IIB2 (12 day untreated muscle injury), the injured site demonstrated regenerating myotubes intermingling with mononuclear inflammatory infiltrate and many small blood vessels. Moreover, macrophages with abundant cytoplasm and large nuclei together with dispersed myoblastic cells could be seen (Figure 8). Same findings were found in semithin sections. 
On the other hand, Hx\&E and semithin sections of subgroup IIIB (12 day treated muscle injury) showed newly formed myofibers with incomplete striations together with well developed newly formed striated longitudinal muscle bundles containing peripheral flattened nuclei while other newly formed bundles appeared with row of internal vesiculated nuclei and grouping in other areas (Figures 9,10).

On observation of Hx\&E of subgroup IIB3 (28 day untreated muscle injury), the injured site demonstrated different grades of muscle fibers maturity. Some appeared with peripherally elongated nuclei while others showed centerly vesicular ones (Figure 11).

Examination of Hx\&E sections obtained from subgroup IIIB3 (28 day treated muscle injury) revealed cross striated muscle fibers with the appearance of elongated vesicular nuclei, some of them appeared in groups while others were seen in centerly situated rows (Figure 12). The delicate connective tissue framework surrounding the muscle fibers showed bizzare shaped macrophages with large nuclei and abundant cytoplasm (Figure 13). Semithin sections demonstrated the cross striation of well developed muscle fibers formed of alternating light and dark bands together with peripherally situated flattened nuclei within muscle fibers. Peripheral elongated vesicular nuclei together with thin connective tissue called endomysium inbetween muscle fibers could be seen (Figure 14).

Masson`s Trichrome sections in control group demonstrated collagenous connective tissue inbetween the muscle fibers appearing bluish in colour (Figure 15). In 5 days untreated injury, sections revealed heavy condensation of bluish coloured collagen bundles within the injured site (Figure 16) while in 5 days treated injury sections showed regenerating purple myofibers within bluish green densly packed collagen bundles (Figure 17).

Masson's Trichrome sections in 12 days untreated group revealed small patches of regenerating myotubes growing within dense collagenous bundles with different grades of intensity varying between dark and light colour (Figure 18) while in 12 days treated injury, sections demonstrated fine network of collagen fibers together with newly formed myofibers (Figure 19).

Masson 's Trichrome sections in 28 days untreated injury showed newly formed myofibers among apparently moderately packed collagen fibers intermingling with densely packed ones (Figure 20) while in 28 days treated injury, sections revealed fine collagenous greenish blue connective tissue inbetween muscle fibers (Figure 21).

Desmin immunohistochemical staining of skeletal muscle in control group appeared as strong striated staining pattern brownish in colour (Figure 22). In 5 day untreated muscle injury, desmin appeared with faint disrupted striations in some areas \& very faint in other areas (Figure 23) while in 5 day treated injury group, it appeared as faint heterogenous striations (Figure 24).
Desmin immunohistochemical staining of skeletal muscle in 12 day untreated muscle injury appeared as variable colour intensities ranging between dark and faint muscle patches (Figure 25) while in 12 day treated injury, it showed brownish cross striated muscle bundles (Figure 26).

Desmin immunohistochemical staining of skeletal muscle in 28 day untreated injury showed cross striated muscle bundles (black star) intermingling with faint ones (Figure 27) while in 28 day treated injury, it appeared as strong striated staining pattern (Figure 28).

\section{Morphometric Results}

In the present study, sham operated rats of group IIB $(\mathrm{B} 1, \mathrm{~B} 2, \mathrm{~B} 3)$ and lidocaine injected rats of group IIIB $(\mathrm{B} 1, \mathrm{~B} 2 \& \mathrm{~B} 3)$ and showed statistical non-significant difference $(p>0.05)$ in the mean number of regenerating cells, macrophages and percentage of collagen deposition on day 5,12 and 28 compared to control group I without intervention.

\section{Regenerating cells count}

Untreated group of muscle injury (compared to control group) (Table 1 and Histogram 1):

On day 5, 12 and 28 muscle injury counting the number of regenerating cells in Hx\&E stained sections (under high power field of light microscope $\mathrm{x} 400$ ) showed statistically highly significant increase compared to control groups.

Treated group of muscle injury (compared to untreated group) (Table 2 and Histogram 1):

On day 5 muscle injury treated with dextrose prolotherapy, counting the number of regenerating cells showed statistically highly significant increase compared to untreated day 5 muscle injury group.

On day 12 muscle injury treated with dextrose prolotherapy, counting the number of regenerating cells showed statistically significant decrease compared to untreated day 12 muscle injury group.

On day 28 muscle injury treated with dextrose prolotherapy, counting the number of regenerating cells showed statistically highly significant decrease compared to untreated day 28 muscle injury group.

\section{Macrophages count}

Untreated group of muscle injury (compared to control group) (Table 3 and Histogram 2):

On day 5, 12 and 28 muscle injury counting the number of macrophages cells in Hx\&E stained sections (under high power field of light microscope x400) showed statistically highly significant increase compared to control groups.

Treated group of muscle injury (compared to untreated group) (Table 4 and Histogram 2):

On day 5 muscle injury treated with dextrose prolotherapy counting the number of macrophages showed 
statistically significant decrease compared to untreated day 5 muscle injury group.

On day 12 and 28 muscle injury treated with dextrose prolotherapy counting the number of macrophages showed statistically highly significant decrease compared to untreated muscle injury groups.

\section{Area percent of collagen fibers deposition (fibrosis)}

Untreated group of muscle injury (compared to control group) (Table 5 and Histogram 3):

On day 5, 12 and 28 muscle injury, the area percent of collagen fibers deposition in Masson`s Trichrome stained sections (under high power field of light microscope x100), showed a statistically highly significant increase compared to control groups.

Treated group of muscle injury (compared to untreated group) (Table 6 and Histogram 3):

On day 5, 12 and 28 muscle injury treated with dextrose prolotherapy revealed the percentage of collagen deposition with statistically highly significant decrease compared to untreated muscle injury groups.

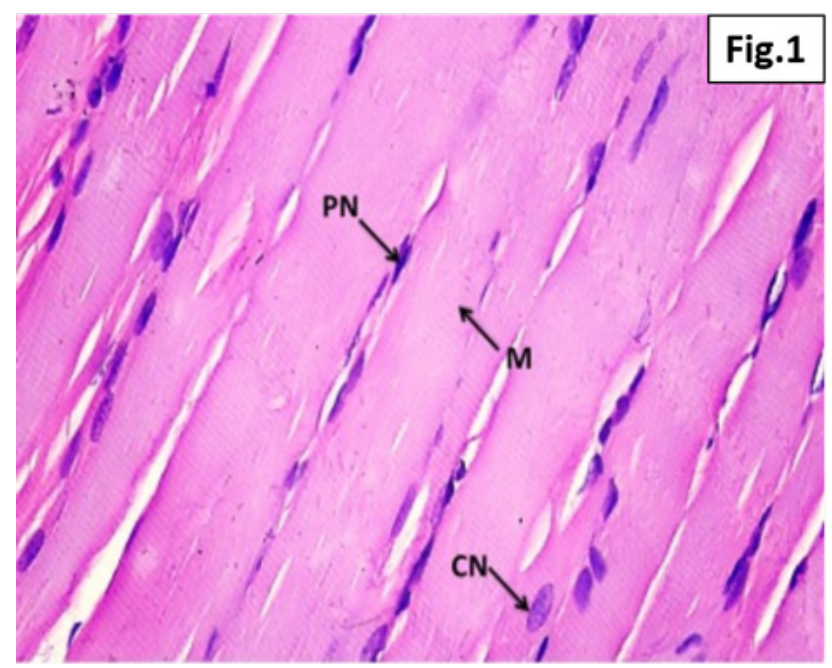

Fig. 1: A photomicrograph of longitudinal section of rat's gastrocnemius muscle of control group (group I) showing cross striated muscle fibers (M) with spindle shaped flattened peripheral nuclei (PN). Notice the appearance of centrely located elongated nuclei $(\mathrm{CN})$ within some muscle fibers. Hx\&E x 400

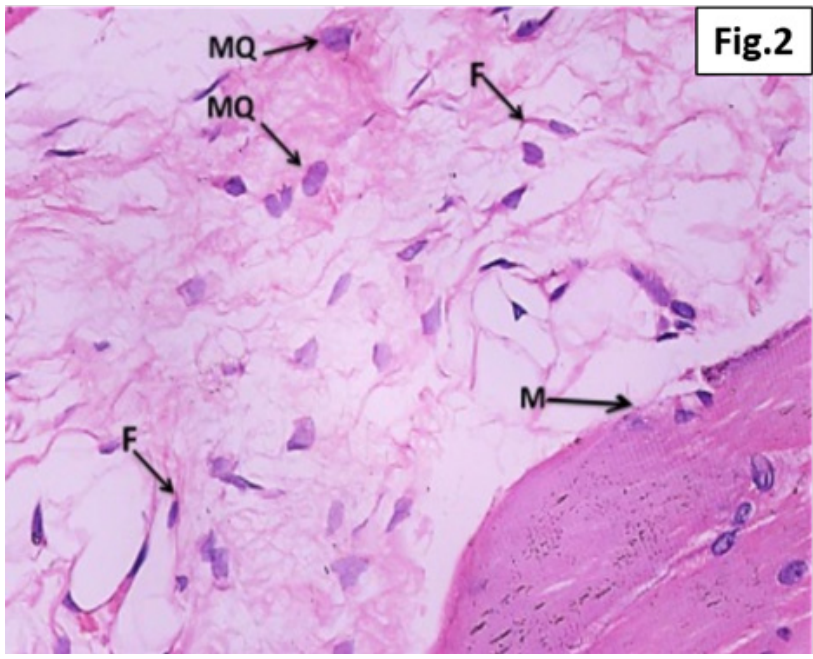

Fig. 2: A photomicrograph of longitudinal section of rat's gastrocnemius muscle of control group (group I) showing bizzare shaped macrophages (MQ) and spindle shaped fibroblasts (F) among delicate connective tissue surrounding the muscle fibers. $\mathrm{M}=$ gastrocnemius muscle. $\mathrm{Hx} \& \mathrm{E}$ x 400

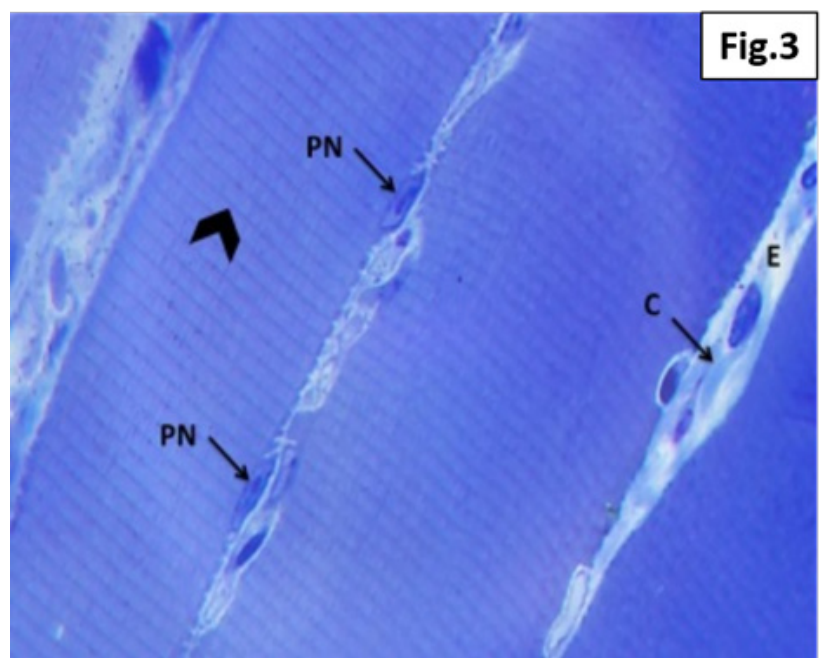

Fig. 3: A photomicrograph of longitudinal semithin section of rat's gastrocnemius muscle of control group (group I) showing prominent cross striations of skeletal muscle fibers formed of alternating light and dark bands (arrow-head). Notice the appearance of peripherally situated flattened nuclei (PN) with prominent nucleoli within muscle fibers. Notice also the connective tissue sheath endomysium (E) inbetween muscle fibers containing delicate collagen fibers $(\mathrm{C})$. Toluidine blue x 1000 


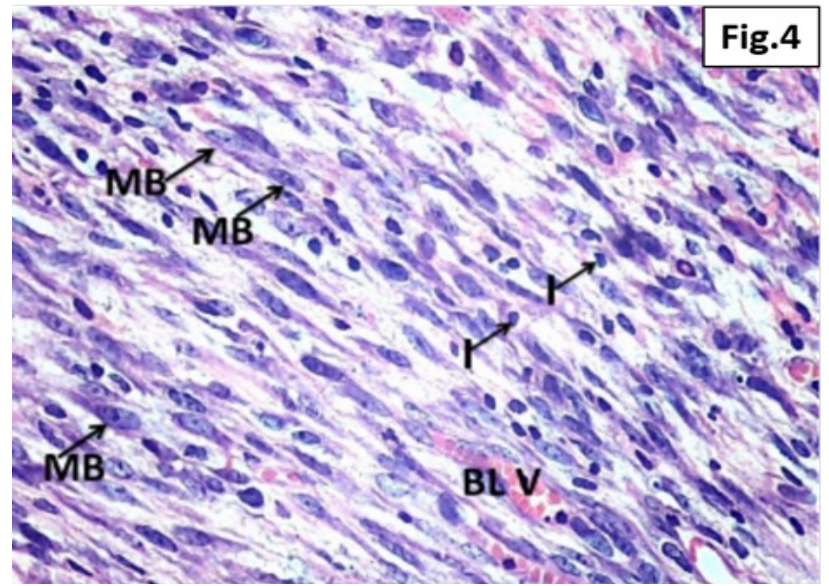

Fig. 4: A photomicrograph of longitudinal section of rat's gastrocnemius muscle of subgroup IIB1 (5 day untreated muscle injury) showing intense infiltration of mononucleated inflammatory cells (I) among granulation tissue intermingling with dispersed myoblastic cells having oval vesicular nuclei and prominent nucleoli (MB) together with congested blood vessel (BL.V). Hx\&E x 400

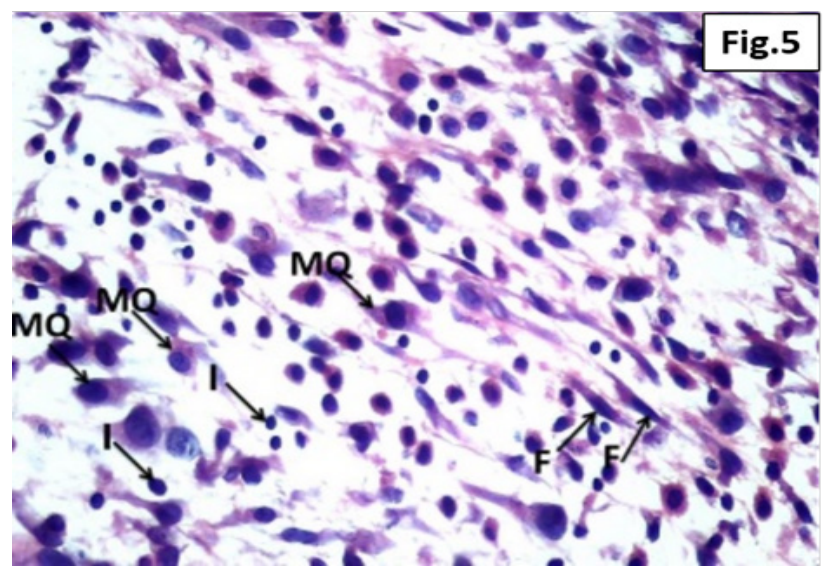

Fig. 5: A photomicrograph of longitudinal section of rat's gastrocnemius muscle of subgroup IIB1 (5 day untreated muscle injury) showing the interstitial space with intense cellular infiltrate. Notice spindle shaped fibroblasts (F), bizzare shaped macrophages (MQ) with mononucleated inflammatory cells (I). Hx\&E x400

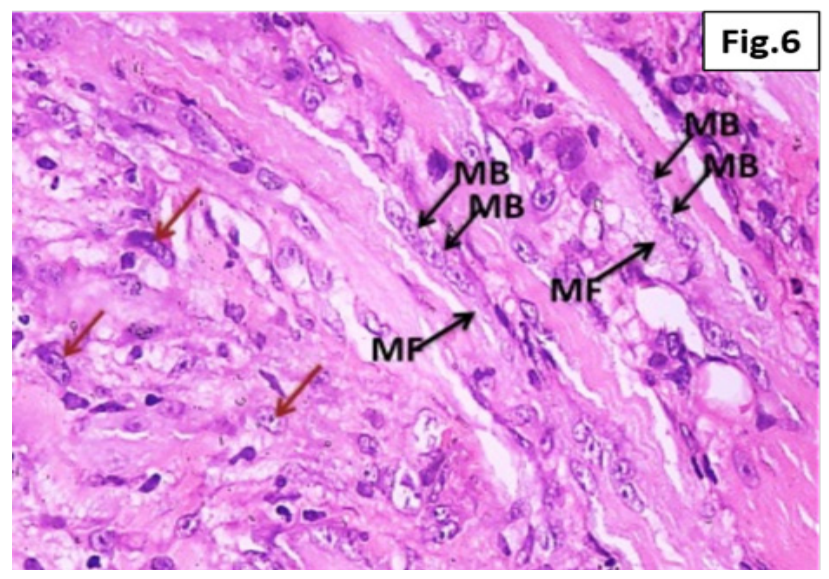

Fig. 6: A photomicrograph of longitudinal section of rat's gastrocnemius muscle of subgroup IIIB1 (5 day muscle injury treated with dextrose prolotherapy) showing a row of internal vesiculated nuclei (MB) in a regenerating myofiber (MF). Notice the appearance of some dispersed vesicular nuclei of myoblastic cells (red arrow). Hx\&E x400

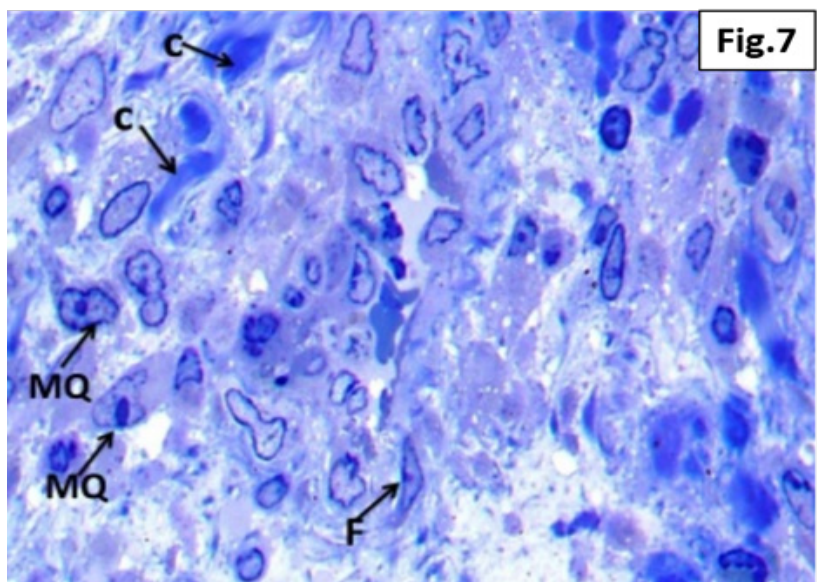

Fig. 7: A photomicrograph of longitudinal semithin section of rat's gastrocnemius muscle of subgroup IIIB1 ( 5 day muscle injury treated with dextrose prolotherapy) showing bundles of collagen fibers $(\mathrm{C})$. Notice the presence of bizzare shaped macrophages with abundant cytoplasm, large nuclei and prominent nucleoli (MQ). $\mathrm{F}=$ spindle shaped fibroblast with flattened nucleus. Toluidine blue $\times 1000$

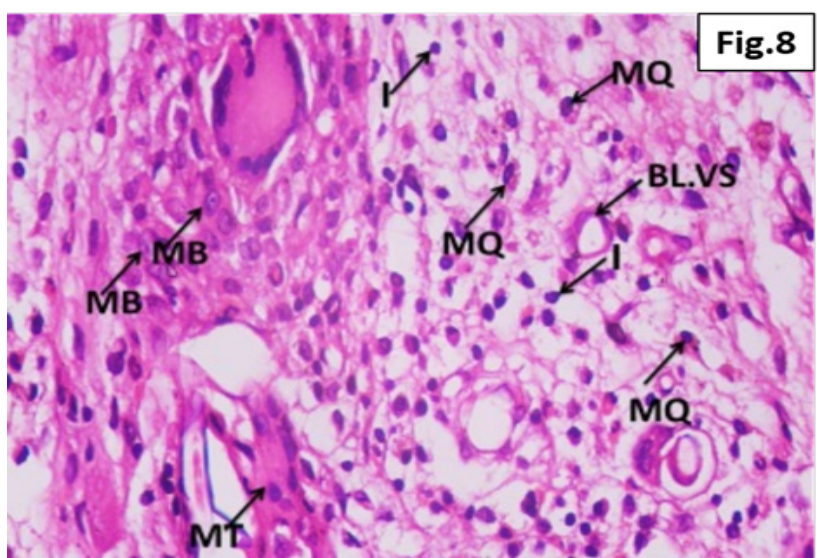

Fig. 8: A photomicrograph of longitudinal section of rat's gastrocnemius muscle of subgroup IIB2 (12 day untreated muscle injury) showing patches of regenerating myotubes (MT) intermingling with mononucleated inflammatory cells (I) and macrophages (MQ). Notice the appearance of dispersed myoblastic cells (MB). Notice also the appearance of many small newly formed blood vessels (BL.vs). Hx\&E x400

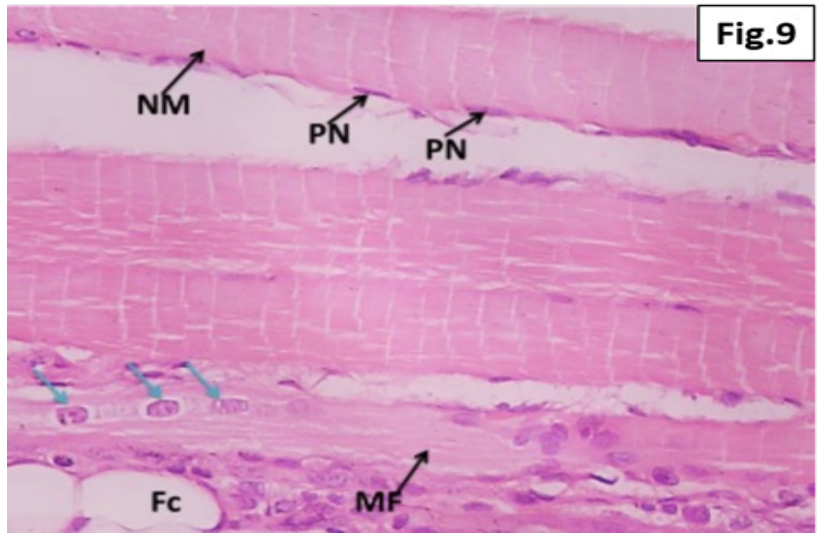

Fig. 9: A photomicrograph of longitudinal section of rat`s gastrocnemius muscle of subgroup IIIB2 (12 day muscle injury treated with dextrose prolotherapy) showing well developed newly formed striated longitudinal muscle bundles (NM) with flattened peripheral nuclei (PN). Notice the appearance of adjacent newly formed regenerating myofibers with incomplete striations (MF) and with row of internal vesiculated nuclei (blue arrow). $\mathrm{Fc}=$ fat cells $\mathrm{Hx} \& \mathrm{E} \times 400$ 


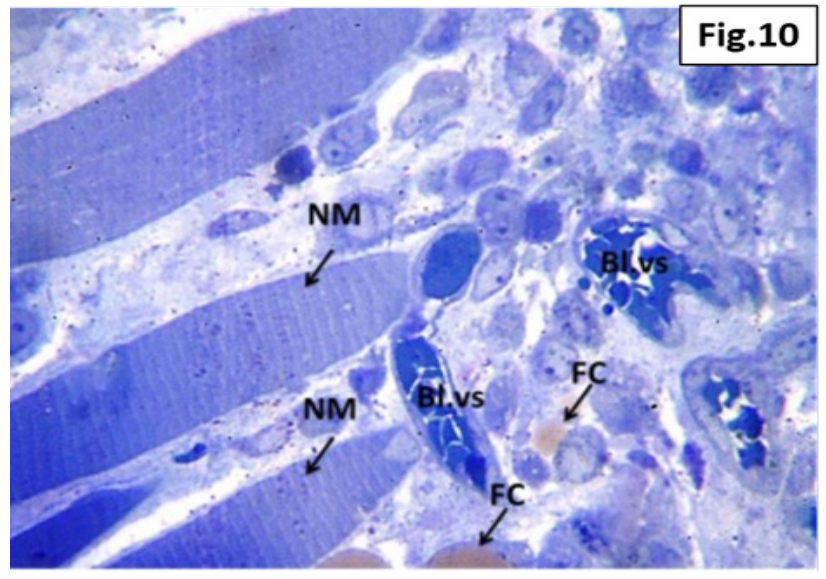

Fig. 10: A photomicrograph of longitudinal semithin section of rat's gastrocnemius muscle of subgroup IIIB2 (12 day muscle injury treated with dextrose prolotherapy) showing well developed newly formed striated muscle bundles (NM) together with newly formed blood vessels (BL.vs) in the injured site. $\mathrm{FC}=$ part of fat cells. Toluidine blue $\mathrm{x} 1000$

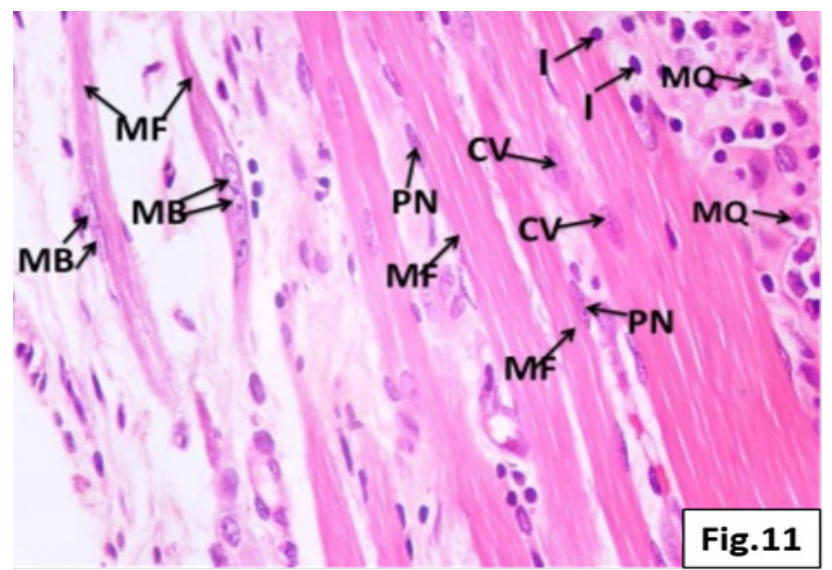

Fig. 11: A photomicrograph of longitudinal section of rat's gastrocnemius muscle of subgroup IIB3 (28 day untreated muscle injury) showing different grades of muscle fibers maturity. Notice the presence of myofibers $(\mathrm{MF})$ with peripherally elongated nuclei $(\mathrm{PN})$ together with others with centerly vesicular (CV) ones. Notice also newly formed myofibers (MF) with a row of internal vesiculated nuclei of myoblastic cells $(\mathrm{MB}) . \quad \mathrm{MQ}=$ macrophages, $\mathrm{I}=$ inflammatory cells $\mathrm{Hx} \& \mathrm{E} \times 400$

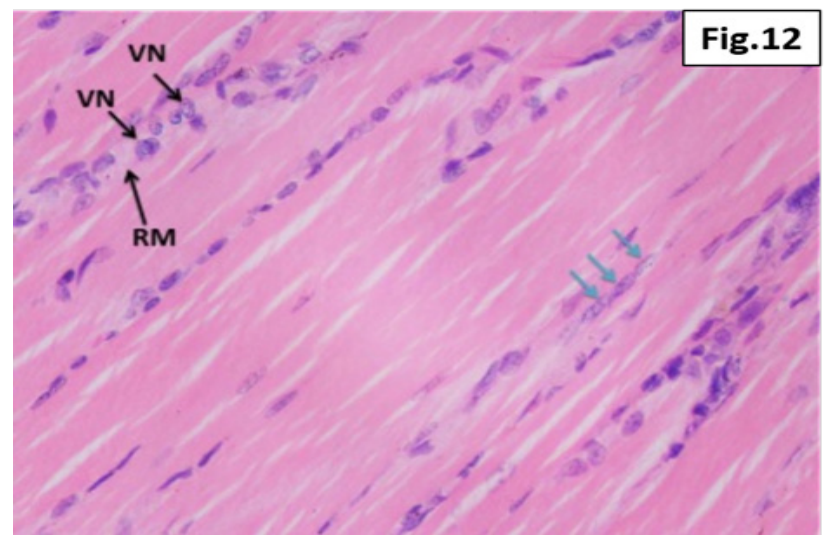

Fig. 12: A photomicrograph of longitudinal section of rat's gastrocnemius muscle of subgroup IIIB3 (28 day muscle injury treated with dextrose prolotherapy) showing grouping of elongated vesicular nuclei (VN) within some newly formed regenerating muscle fibers (RM). Notice the appearance of a row of internal vesiculated nuclei (blue arrow) in other areas. Hx\&E $\mathrm{x} 400$

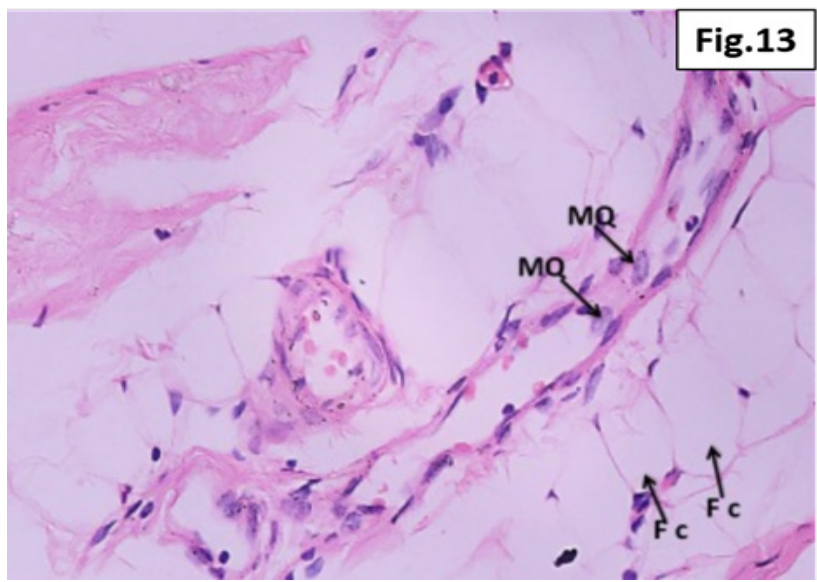

Fig. 13: A photomicrograph of longitudinal section of rat's gastrocnemius muscle of subgroup IIIB3 (28 day muscle injury treated with dextrose prolotherapy) showing bizzare shaped macrophages (MQ) among delicate connective tissue surrounding the muscle fibers. Notice the presence of vacuolated fat cells $(\mathrm{Fc})$ with signet ring appearance. Hx\&E x400

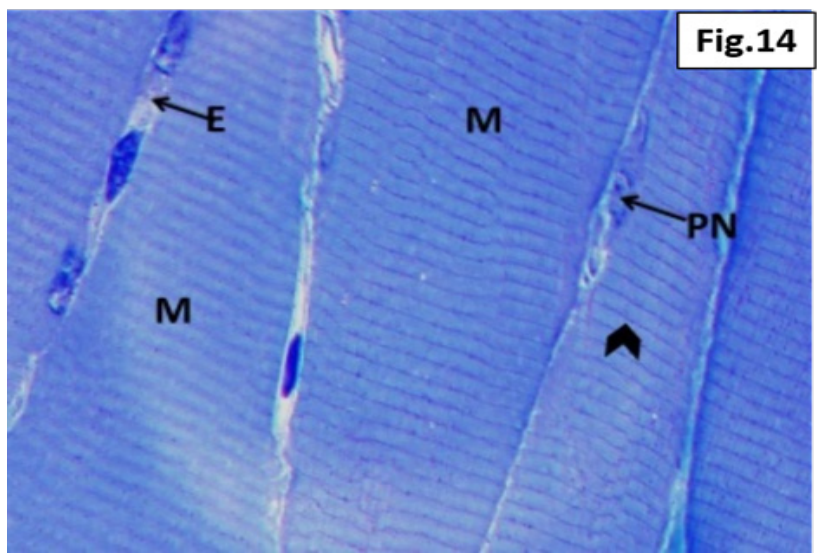

Fig. 14: A photomicrograph of longitudinal semithin section of rat's gastrocnemius muscle of subgroup IIIB3 (28 day muscle injury treated with dextrose prolotherapy) showing the cross striation of well developed muscle fibers (M) formed of alternating light and dark bands (arrow head). Notice the appearance of peripherally elongated vesicular nuclei $(\mathrm{PN})$. Notice also thin connective tissue endomysium (E) inbetween muscle fibers Toluidine blue x 1000

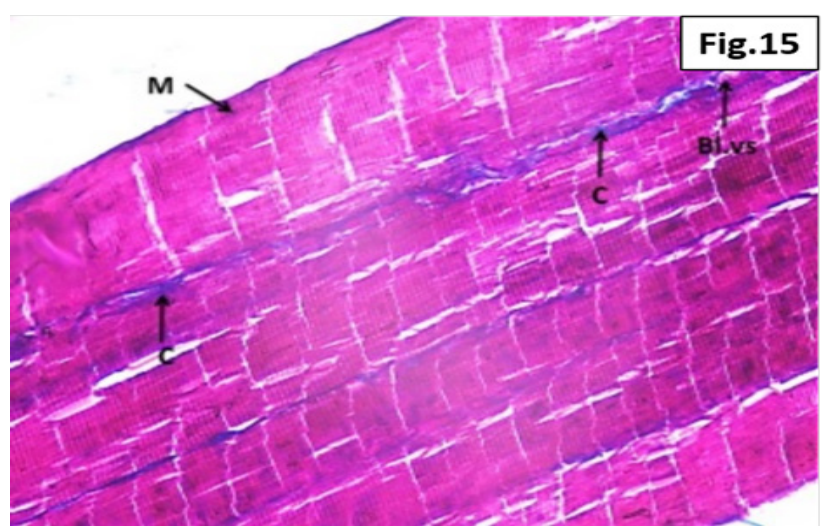

Fig. 15: A photomicrograph of longitudinal section of rat's gastrocnemius muscle of control group (group I) showing collagenous connective tissue (C) inbetween muscle fibers (M) appearing bluish in colour together with blood vessels (B1.vs). Masson`s Trichrome x400 


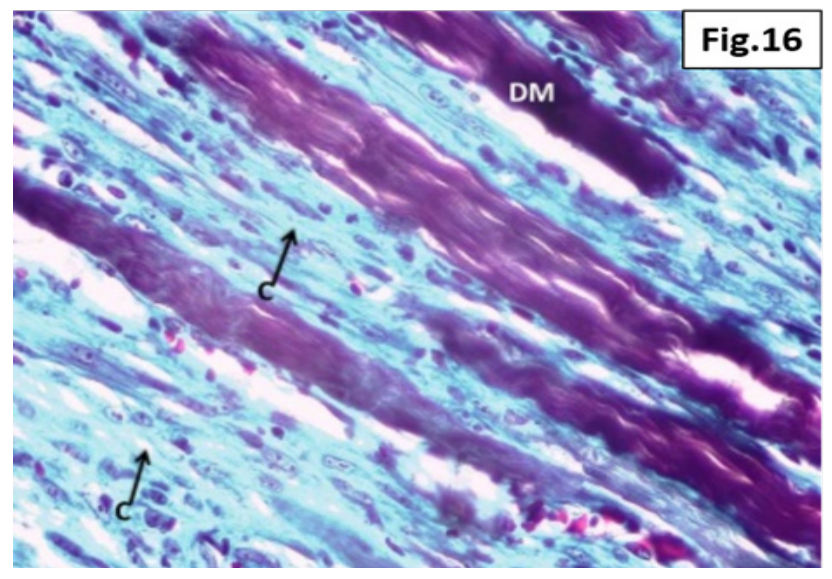

Fig. 16: A photomicrograph of longitudinal section of rat's gastrocnemius muscle of subgroup IIB1 (5 day untreated muscle injury) showing condensation of collagen bundles $(C)$ within the injured site. DM= degenerated muscle fibers Masson`s Trichrome x400

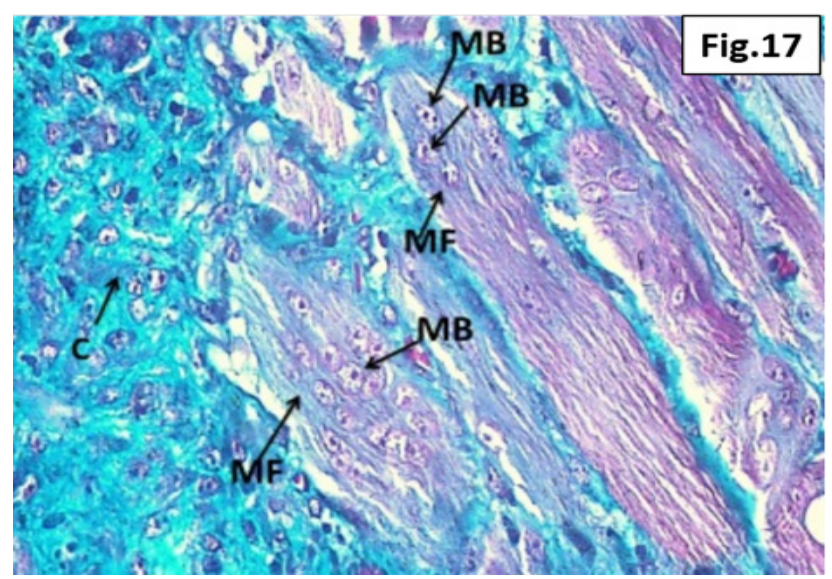

Fig. 17: A photomicrograph of longitudinal section of rat's gastrocnemius muscle of subgroup IIIB1 (5 day muscle injury treated with dextrose prolotherapy) showing regenerating myofibers (MF) growing within densly packed blue greenish collagen bundles $(C) . M B=$ myoblastic cells Masson`s Trichrome x400

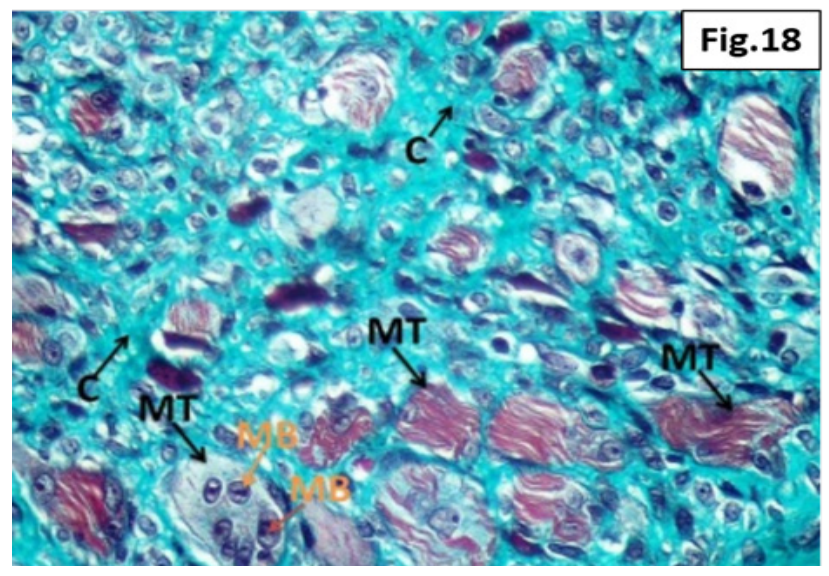

Fig. 18: A photomicrograph of longitudinal section of rat's gastrocnemius muscle of subgroup IIB2 (12 day untreated muscle injury) showing patches of regenerating myotubes (MT) growing within thick dense bundles of collagen fibers $(\mathrm{C})$. Orange arrow $=$ grouping of internal vesiculated nuclei of myoblastic cells (MB) in some regenerating myotubes (MT). Masson Trichrome`s x 100

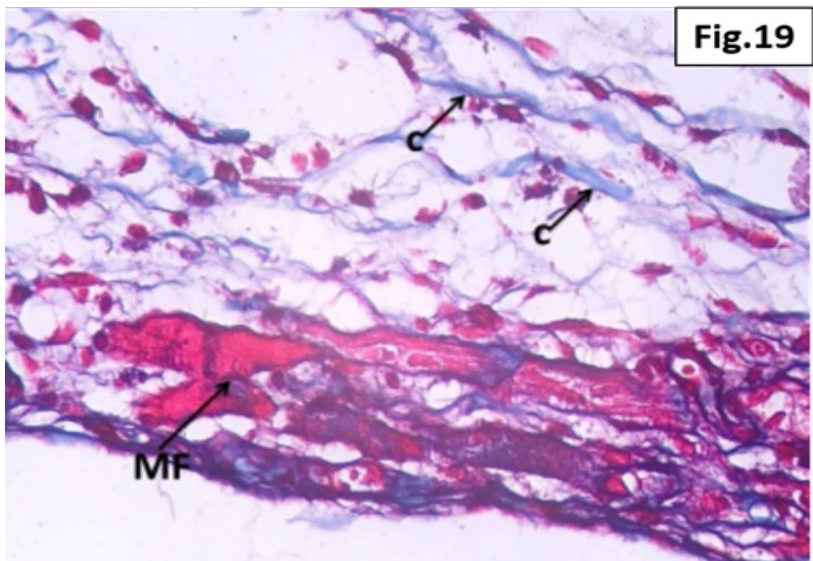

Fig. 19: A photomicrograph of longitudinal section of rat's gastrocnemius muscle of subgroup IIIB2 (12 day muscle injury treated with dextrose prolotherapy) showing fine network of collagen fibers (C) intermingling with newly formed myofibers (MF). Masson`s Trichrome x400

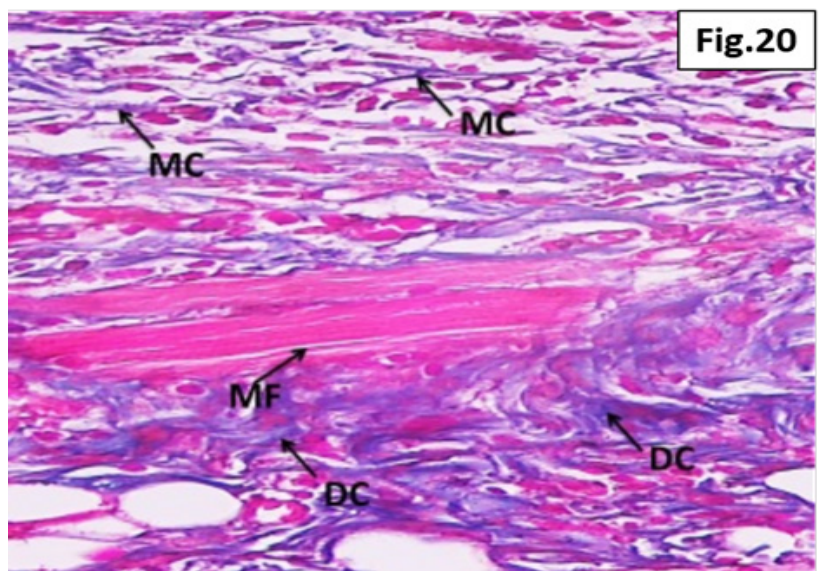

Fig. 20: A photomicrograph of longitudinal section of rat's gastrocnemius muscle of subgroup IIB3 (28 day untreated muscle injury) showing different grades of collagen condensation ranging from moderately packed collagen fibers (MC) to densly packed collagen bundles (DC) $\mathrm{MF}=$ newly formed myofibers. Masson`s Trichrome $\mathrm{x} 400$

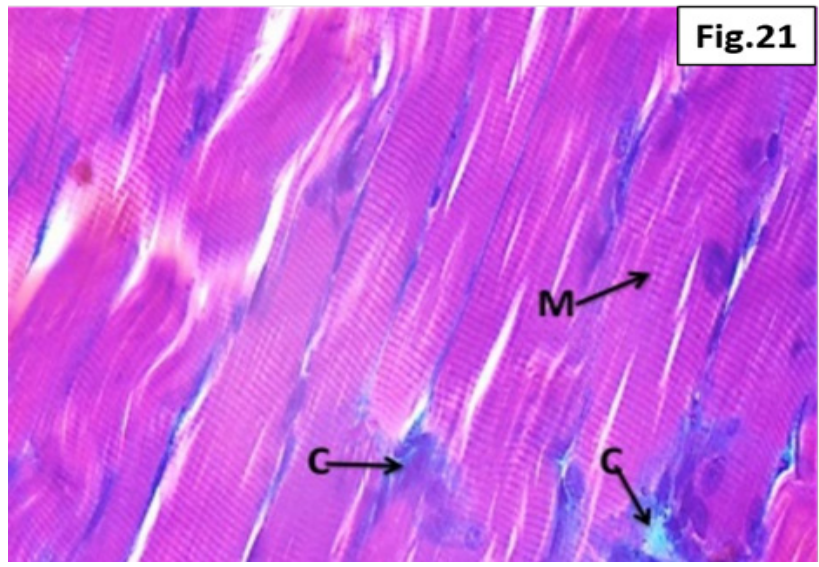

Fig. 21: A photomicrograph of longitudinal semithin section of rat's gastrocnemius muscle of subgroup IIIB3 (28 day muscle injury treated with dextrose prolotherapy) showing fine collagenous connective tissue (C) in between muscle fibers (M) appearing greenish blue in colour. Masson`s Trichrome x 400 


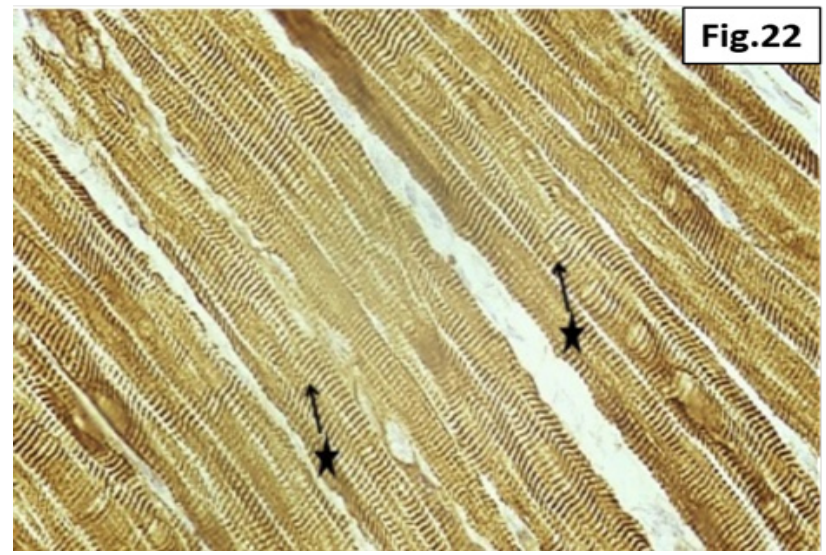

Fig. 22: A photomicrograph of longitudinal section of rat's gastrocnemius muscle of control group (group I) showing desmin immunohistochemical staining of skeletal muscles with strong striated staining pattern (black star) Desmin immunohistochemistry x 400

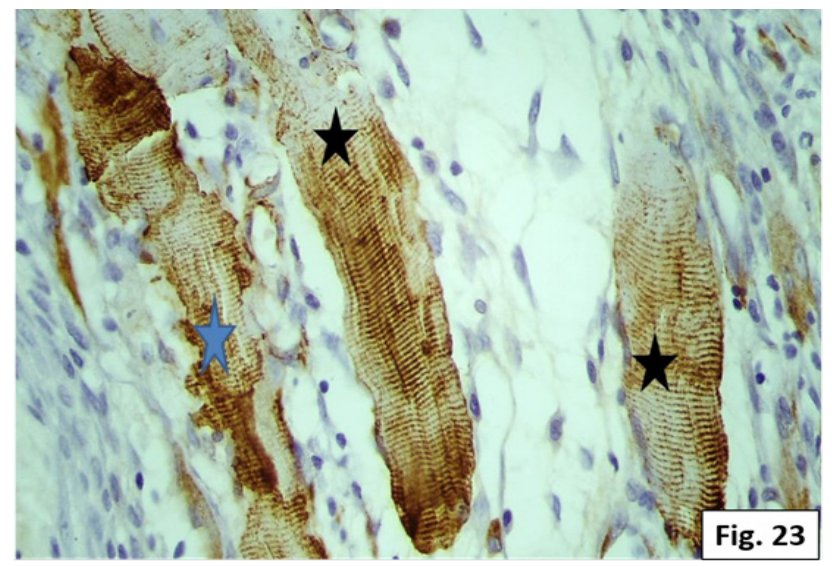

Fig. 23: A photomicrograph of longitudinal section of rat's gastrocnemius muscle of subgroup IIB1 (5 day untreated muscle injury) showing desmin immunohistochemical staining of skeletal muscle with faint disrupted striations (black star) in some areas \& very faint in other areas (blue star) Desmin immunohistochemistry x 400

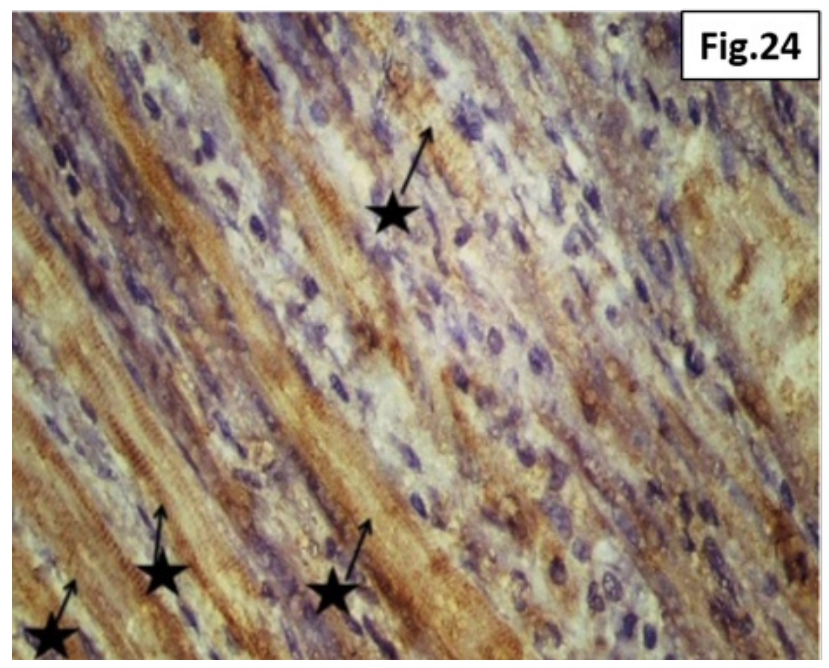

Fig. 24: A photomicrograph of longitudinal section of rat's gastrocnemius muscle of subgroup IIIB1 (5 day treated muscle injury) showing desmin immunohistochemical staining of skeletal muscle with faint heterogoneus striations (black star) Desmin immunohistochemistry x 400

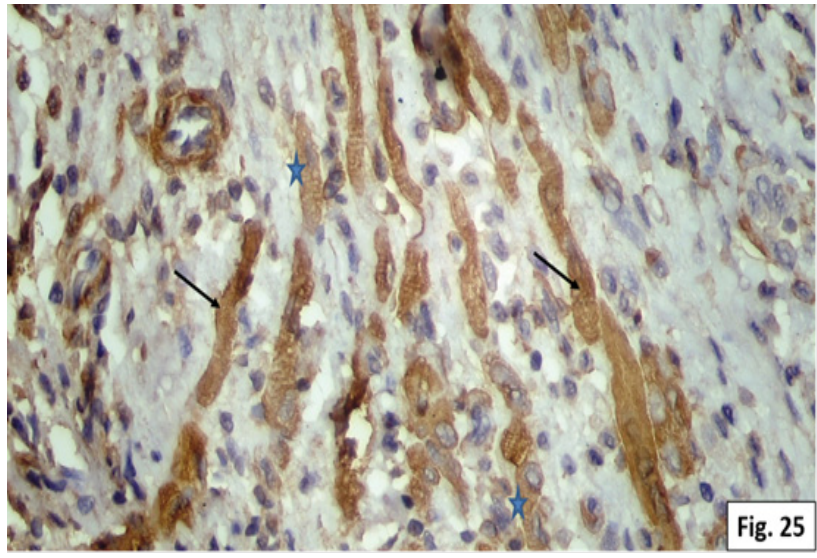

Fig. 25: A photomicrograph of longitudinal section of rat's gastrocnemius muscle of subgroup IIB2 ( 12 day untreated muscle injury) showing desmin immunohistochemical staining of skeletal muscle with variable colour intensities ranging between dark (black arrow) and faint ( blue star ) muscle patches Desmin immunohistochemistry x 400

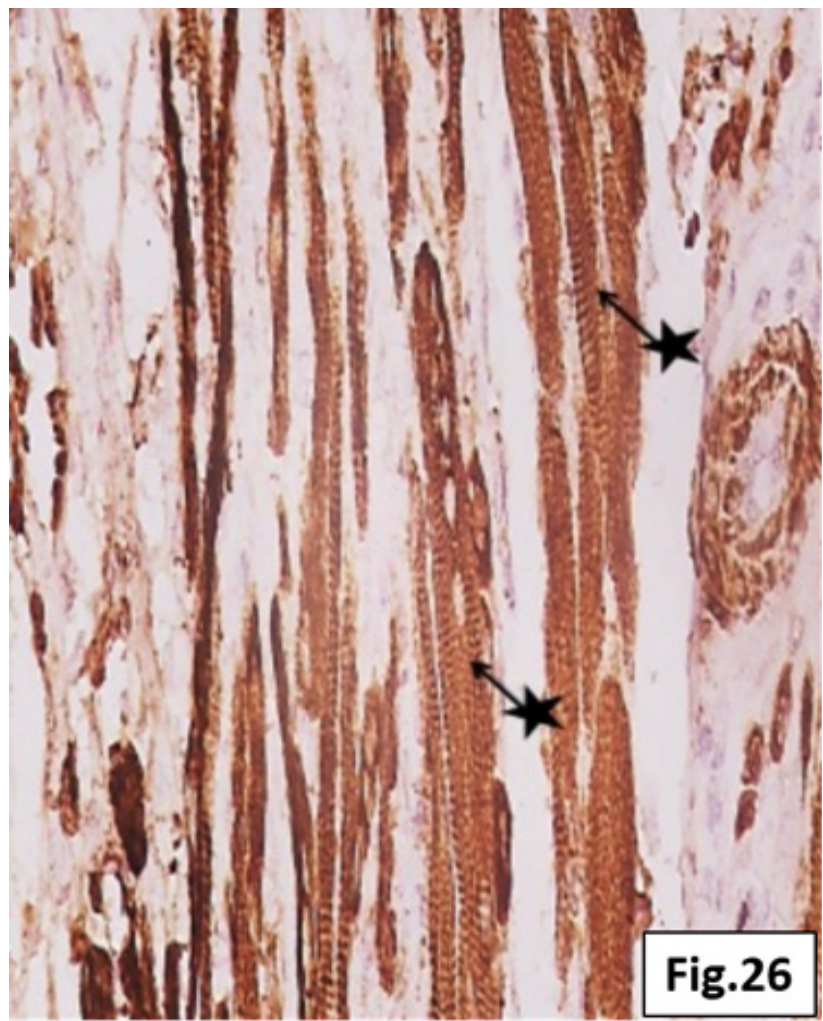

Fig. 26: A photomicrograph of longitudinal section of rat's gastrocnemius muscle of subgroup IIIB2 ( 12 day treated muscle injury) showing desmin immunohistochemical staining of skeletal muscle with cross striated muscle bundles in most areas( black star )Desmin immunohistochemistry $\mathrm{x} 400$ 


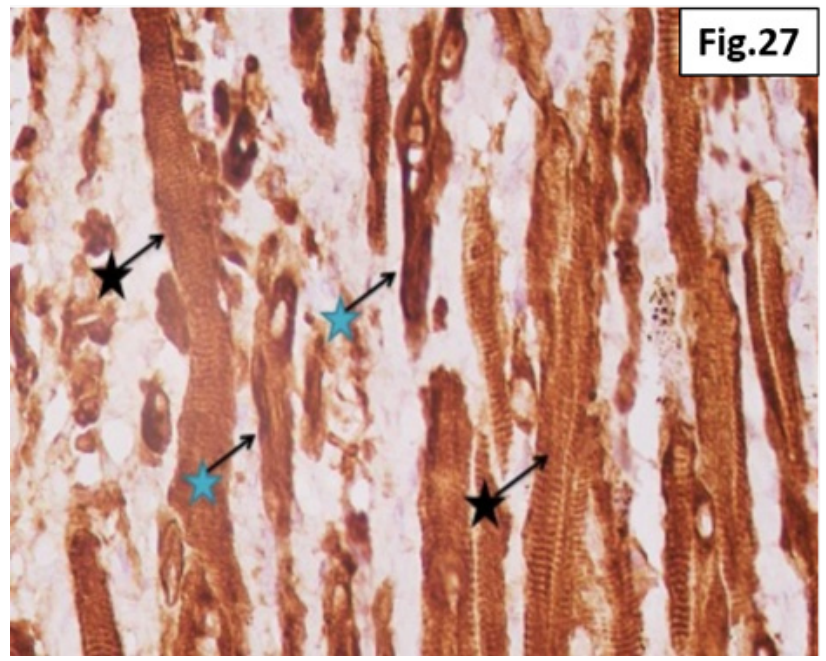

Fig. 27: A photomicrograph of longitudinal section of rat's gastrocnemius muscle of subgroup IIB3 (28 day untreated muscle injury) showing desmin immunohistochemical staining of skeletal muscle with cross striated muscle bundles (black star) intermingling with faint ones (blue star) Desmin immunohistochemistry x 400

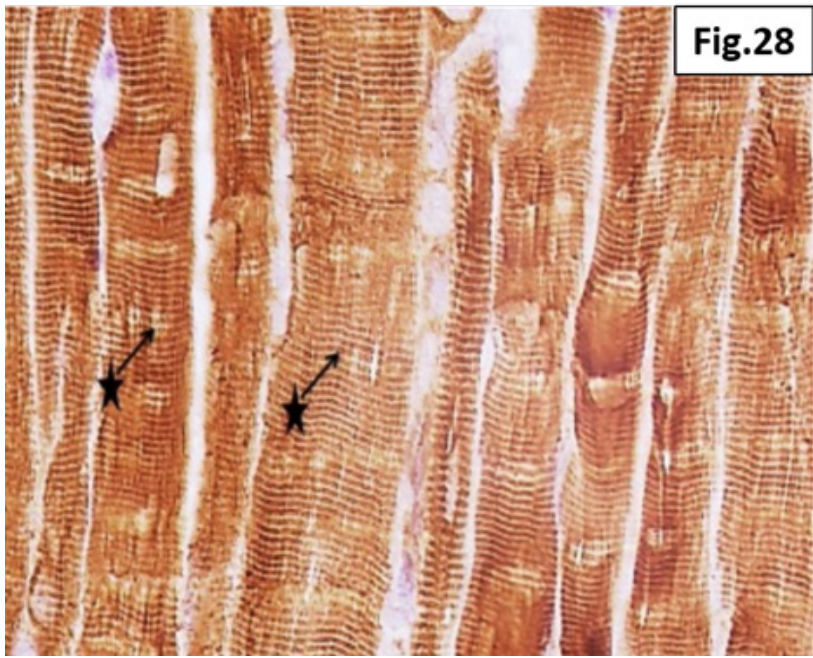

Fig. 28: A photomicrograph of longitudinal section of rat's gastrocnemiu muscle of subgroup IIIB3 ( 28 day treated muscle injury ) showing desmin immunohistochemical staining of skeletal muscle with strong cross striated staining pattern (black arrow) Desmin immunohistochemistry x 400

Table 1: The mean number of regenerating cells among untreated groups

\begin{tabular}{ccccc}
\hline Days & Groups & Mean & +/-SEM & $P$ value (compared to control groups) \\
\hline \multirow{2}{*}{ Day 5 } & Control & 1.5 & 1.36 & $8.38 \mathrm{E}-11^{* * *}$ \\
& untreated group & 29.5 & 6.1 & $4.09 \mathrm{E}-10^{* * *}$ \\
\multirow{2}{*}{ Day 12 } & Control & 1.79 & 7.59 & 7.3 \\
& Untreated group & 32.2 & 1.42 & $6.34 \mathrm{E}-06^{* * *}$ \\
\hline
\end{tabular}

$* *=$ significant increase/decrease compared to untreated group $(P<0.05)$

$* * *=$ highly significant increase/decrease compared to control group $(P<0.001)$

Table 2: The mean number of regenerating cells among the treated groups

\begin{tabular}{ccccc}
\hline Days & Groups & Mean & + -SEM & $P$ value (compared to untreated groups) \\
\hline \multirow{2}{*}{ Day 5 } & Untreated group & 29.5 & 6.1 & $2.88 \mathrm{E}-06^{* * *}$ \\
& Treated group & 56.9 & 10.67 & $1.73 \mathrm{E}-05^{* * * *}$ \\
\multirow{2}{*}{ Day 12 } & Untreated group & 32.2 & 5.3 & 9.8 \\
& Treated group & 14.1 & 4.8 & $9.69 \mathrm{E}-06^{* * * *}$ \\
\multirow{2}{*}{ Day 28 } & Untreated group & 12.01 & 1.51 & \\
& Treated group & 1.9 & \\
\hline
\end{tabular}

$* * *=$ highly significant increase/decrease compared to untreated control group $(P<0.001)$

Table 3: The mean number of macrophages among the untreated groups

\begin{tabular}{ccccc}
\hline Days & Groups & Mean & +/-SEM & P value (compared to control groups) \\
\hline \multirow{2}{*}{ Day 5 } & control & 5 & 2.11 & $1.98 \mathrm{E}-12^{* * * *}$ \\
& Untreated group & 46.7 & 7.86 & $2.75 \mathrm{E}-06^{* * * *}$ \\
Day 12 & control & 4.3 & 2.05 & 11.95 \\
& Untreated group & 31.4 & 2.2 & $1.55 \mathrm{E}-09^{* * * *}$ \\
\multirow{2}{*}{ Day 28 } & control & 4.6 & 3.71 & \\
& Untreated group & 20.7 & \\
\hline
\end{tabular}

$* * *=$ highly significant increase/decrease compared to control group $(P<0.001)$ 
Table 4: The mean number of macrophages among the treated groups

\begin{tabular}{ccccc}
\hline Days & Groups & Mean & +-SEM & $P$ value (compared to untreated groups) \\
\hline \multirow{2}{*}{ Day 5 } & Untreated group & 46.7 & 7.86 & 5.28 \\
& Treated group & 35.9 & 11.95 & $0.003^{* * *}$ \\
\multirow{2}{*}{ Day 12 } & Untreated group & 31.4 & 3.71 & $8.2 \mathrm{E}-05^{* * *}$ \\
& Treated group & 10.3 & 3.71 & $5.19 \mathrm{E}-10^{* * *}$ \\
& Untreated group & 20.7 & 1.62 & \\
\hline
\end{tabular}

$* *=$ significant increase/decrease compared to untreated group $(P<0.05)$

$* * *=$ highly significant increase/decrease compared to untreated control group $(P<0.001)$

Table 5: The mean number of collagen deposition among the untreated groups

\begin{tabular}{ccccc}
\hline Days & Groups & Mean & +/-SEM & $P$ value (compared to control groups) \\
\hline \multirow{2}{*}{ Day 5 } & Control & 3.06 & 0.62 & $1.29 \mathrm{E}-20^{* * *}$ \\
& untreated group & 43.87 & 2.41 & 0.49 \\
Day 12 & Control & 2.8 & 0.38 & $9.76 \mathrm{E}-30^{* *}$ \\
& Untreated group & 35.8 & 0.43 & $3.31 \mathrm{E}-37^{* * *}$ \\
\hline
\end{tabular}

$* * *=$ high significant increase/decrease compared to control group $(P<0.001)$

Table 6: The mean number of the percentage of collagen deposition among the treated groups

\begin{tabular}{ccccc}
\hline Days & Groups & Mean & + -SEM & $P$ value (compared to untreated groups) \\
\hline \multirow{2}{*}{ Day 5 } & Untreated group & 43.87 & 2.41 & $3.19 \mathrm{E}-12^{* * * *}$ \\
& Treated group & 30.57 & 0.38 & 0.38 \\
\multirow{2}{*}{ Day 12 } & Untreated group & 35.8 & 0.08 & $1.9 \mathrm{E}-31^{* * * *}$ \\
& Treated group & 10.17 & 0.47 & $3.59 \mathrm{E}-29^{* * *}$ \\
\hline \multirow{2}{*}{ Day 28 } & Untreated group & 27.3 & 0.06 & 3.81 \\
& Treated group & 3.06 & \\
\hline
\end{tabular}

$* * *=$ highly significant increase/decrease compared to untreated control group $(P<0.001)$

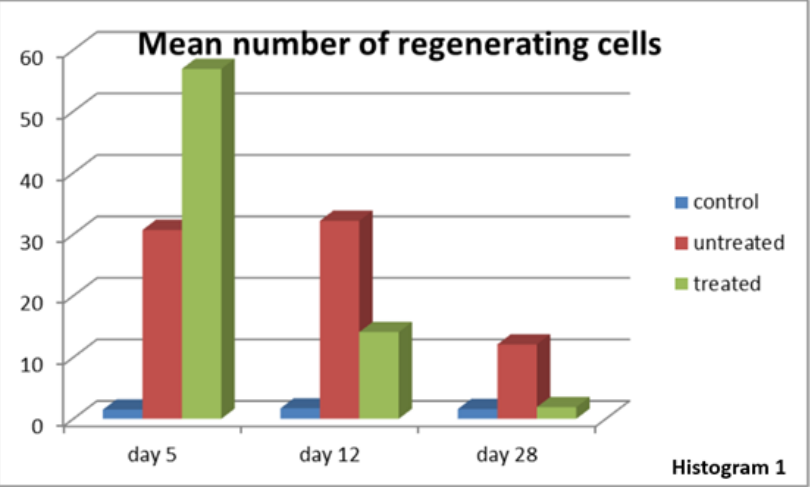

Histogram 1: Mean number of regeneration cells

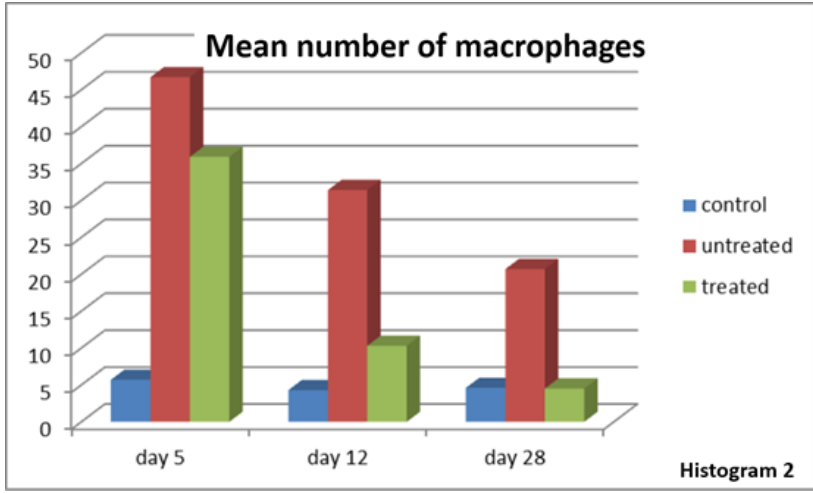

Histogram 2: Mean number of macrophages 


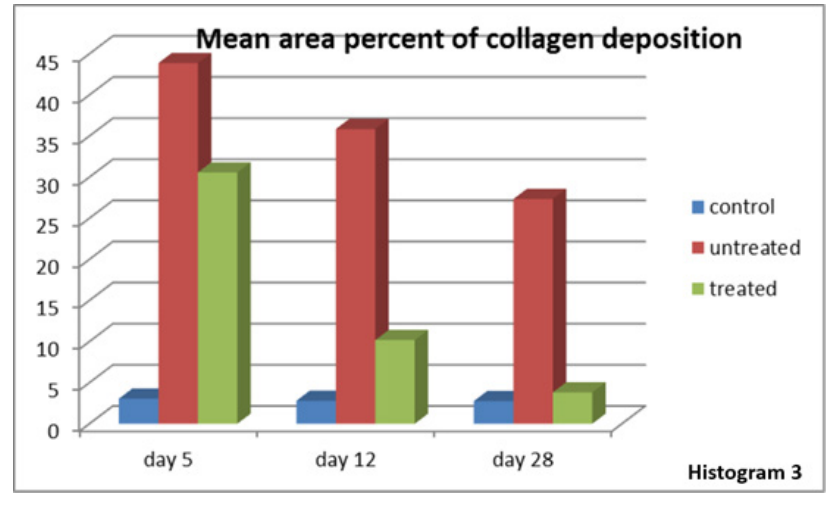

Histogram 3: Mean area percent of collagen deposition.

\section{DISCUSSION}

The current study was designed to evaluate the histological changes induced by the application of dextrose prolotherapy on skeletal muscle injury in normal treated adult male albino rats. Skeletal muscle specimens were examined at three time points $(5,12$ and 28 days) using light microscope for paraffin and semithin sections together with morphometric analysis.

In results of the current study, control untreated muscle, sham operated group and lidocaine injected group demonstrated long non branching striated cylindrical elongated parallel muscle fibers with multiple peripherally situated flattened nuclei, some muscle fibers showed peripheral oval elongated vesicular nuclei representing satellite cells. This was previously described by ${ }^{[18-20]}$. who illustrated that normal muscle fibers appeared as long cylindrical parallel fibers having multiple flattened peripheral nuclei and transverse striations Moreover, bizzare shaped macrophages with abundant cytoplasm and large nuclei together with spindle shaped fibroblasts having flattened nuclei were seen among delicate connective tissue surrounding muscle fibers, this was explained by ${ }^{[21,22]}$. who stated that resident macrophages and fibroblasts are located in epimysium and perimysium of normal muscle fibers. macrophages orchestrate immune response to tissue injury while fibroblasts produce fine collagen type III.

Masson trichrome stained sections revealed collagenous condensation with blood vessels inbetween muscle fibers. Garg et al stated that extracellular matrix is formed of basal lamina and interstitial matrix. It provides anatomical organization of the muscle in which the endomysium that surrounds each individual myofiber contains collagen III, the perimysium that surrounds groups of myofibers to form fascicles contains primarily collagen I and finally the epimysium that surrounds each muscle contains collagen III $^{[22]}$.

Furtheremore, examination of desmin immunohistochemiocal staining of skeletal muscle fibers appeared as strong striated pattern as described by ${ }^{[20,23]}$. who illustrated that normal muscle fibers show positive desmin.
In the present study, 5 day untreated muscle injury showed apparently intense infiltration of inflammatory cells as eosinophils and lymophocytes over area of muscular discontinuity together with numerous bizzare shaped macrophages and spindle shaped fibroblasts having flattened nuclei in the widened interstitial space, the current results were in accordance with previous studies reported by ${ }^{[18-20]}$. Moreover ${ }^{[1,21,25,26]}$. stated that within first day after injury, inflammatory cells secrete large number of proinflammatory mediators as cytokines and growth factors that create a chemoattractive microenviroment for other inflammatory cells as monocytes which become macrophages in tissue spaces, lymophocytes and eosinophils which invade the gap between disrupted muscle fibers have strong phagocytic activity which help in removal of cellular debris. This was in agreement with the present study which demonstrated heavy macrophages infiltration in the injured site confirmed by statistically highly significant increase in the number of macrophages in 5 days untreated group compared to normal. However, in group 5 day muscle injury that was treated by dextrose prolotherapy, Hx\&E and semithin sections demonstrated regenerating newly formed myofibers together with multiple fused rows of internal vesiculated nuclei, somes areas showed dispersed myoblastic nuclei, The number of regenerating cells in this group showed highly significant increase compared to 5 day untreated group. Sections revealed also bizzare shaped macrophages with abundant cytoplasm and large nuclei which showed statistically significant decrease compared to 5 days untreated injury group., this was also revealed by desmin immunohistochemical staining of regenerating skeletal muscle which showed faint heterogenous striations. This was in accordance with previous studies reported by Moreover, Menetrey (2000), Anderson et al. (2015) and Siadat el al. (2019) added that dextrose prolotherapy stimulates the release of multiple growth factors as platelet derived growth factor (PDGF), fibroblast growth factor (FGF) and insulin growth factor (IGF). PDGF and FGF aid myoblast proliferation and fusion and increase myoblastic migration to the injured site through inhibition of MyoD expression and myoblast differentiation while IGF induce myoblast differentiation through stimulating myogenin expression $^{[8,27,28]}$.

In the present study, Hx\&E and semithin sections in 12 day untreated injury group revealed newly formed myotubes with grouping of internal vesiculated nuclei. This group revealed significant increase in the number of regenerating cells compared to control group. Same findings illustrated by Winkler et al. (2011), Ferreira et al. (2015) and Wang et al. (2017) who stated that myocytes with multiple nuclei appeared in fourteen days postinjury forming multinucleated structures, it represents an indicator for muscle regeneration. Furthermore, desmin immunohistochemical staining of regenerating skeletal muscle showed variable colour intensities of striations ranging between dark and faint muscle patches ${ }^{[18,24,29]}$. Prisk and Huard (2003), Karalaki et al. (2009) and Novak et al. (2014) reported that after some rounds of myoblastic 
proliferation by Pax7 expression, some of them upregulate MyoD expression that is responsible for myoblast differentiation but the rest maintain $\operatorname{Pax} 7$ and continue to proliferate slowly, also IGF and M2 macrophages that is released normally at the injured site stimulates myoblast fusion and differentiation ${ }^{[26,30,31]}$.

However, in 12 day treated group, $\mathrm{Hx} \& \mathrm{E}$ and semithin sections revealed well developed newly formed striated longitudinal myofibers having peripheral flattened nuclei together with newly formed myofibers with incomplete striations with rowing of internal vesiculated nuclei, the number of regenerating cells in this group showed highly significant decrease compared to 12 day untreated group. This was explained by Menetrey et al. (2000) and Siadat (2019) who illustrated that dextrose prolotherapy release insulin growth factor (IGF) that induce myoblast differentiation for expression of myogenin and stimulates myosin heavy chain production ${ }^{[8,27]}$. This was demonstrated by desmin immunohistochemical staining of regenerating skeletal cells revealed brownish cross striated muscle bundles, this was illustrated by Tsai et al. (2018) who explained that dextrose prolotherapy can elevate desmin expression within the injured site, prolotherapy in turn promotes the regeneration of muscle fibers ${ }^{[2]}$.

On the other hand, in 28 day untreated injury group, Hx\&E sections revealed regenerated multinucleated myotubules together with different grades of muscle fibers maturity ranging from areas showing rowing of vesiculated nuclei indicating an early stage of muscle regeneration to myofibers with centrally vesiculated nuclei to peripherally elongated ones indicating advanced stage of regeneration. the number of regenerating cells in this group showed statistically highly significant increase compared to control group. The same findings were reported by Novak et al. (2014) and Ferreira et al. (2015), these authors together with Liu et al. (2019) mentioned that M2 macrophages which are abundant in advanced stages of tissue repair process induces myoblast fusion and differentiation ${ }^{[18,31,32]}$. Moreover, desmin immunohistochemical staining of regenerating skeletal muscle cells revealed cross striated muscle bundles intermingling with faint ones. This current result was reported previously by Tsai et al. (2018) who stated that desmin expression steadily increased after injury ${ }^{[2]}$.

However, in 28 day treated injury group, the present study revealed re-establishment of normal architecture of muscle fibers which appeared as cylindrical striated elongated bundles arranged in parallel pattern with peripherally situated flattened nuclei, the number of regenerating cells in this group showed highly significant decrease compared to 28 day untreated group. This was explained by Siadat (2019) who illustrated that dextrose prolotherapy release insulin growth factor (IGF) and connective tissue growth factor (CTGF) that induce myoblast fusion and differentiation. Moreover, desmin immunohistochemical staining of regenerating skeletal cells revealed strong striated staining pattern ${ }^{[8]}$. This current result was reported by Tsai et al. (2010) who that stated that desmin expression was elevated with dextrose prolotherapy ${ }^{[2]}$.

Regarding fibroplasia, In the present study in 5day untreated group, Masson's Trichrome sections revealed heavy deposition of collagen bundles in the newly formed matrix denoting phase of collagen deposition. The area percentage of collagen fibers deposition in this group showed highly significant increase compared to control group, However, in 5 day treated injury, Masson's Trichrome stained sections showed newly formed muscle fibers within densely packed collagen bundles, the area percentage of collagen deposition in this group revealed highly significant decrease compared to 5 day untreated group. This was explained by Kaariainen et al. (2000), Prisk and Huard, (2003) and Karalaki et al. (2009) who stated that local response to injury stimulates the synthesis of collagen very actively as early as third day post injury, at first it is formed of thin collagen fibers (type III) then thick collagen fibers (type I) which becomes increasingly dense over the period of seven to fourteen days post injury and this restrict the regenerative growth of myofibers ${ }^{[26,30,33]}$. Campbell and Dunn, (2012), Hauser et al. (2016) and Siadat (2019) added that dextrose prolotherapy release PDGF and connective tissue growth factor (CTGF) that accelerate fibroblast attraction and proliferation thus promoting extracellular matrix deposition with healing of disrupted collagen fibers ${ }^{[7-9]}$.

Masson`s Trichrome stained sections in 12day untreated injury revealed small patches of regenerated muscle fibers growing within dense collagenous bundles, the area percentage of collagen deposition in this group demonstrated highly significant increase compared to control group. However, In 12 day treated group, sections demonstrated fine network of collagen fibers, the area percent of collagen deposition in this group revealed highly significant decrease compared to 12 day untreated group. Moreover, Kaariainen et al. (2000), Prisk and Huard, (2003) and Garg et al. (2015) stated that dense collagen fibers become increasingly over the course from 7 to 14 days postinjury. Also, authors reported that transforming growth factor beta (TGF beta) is released at the injured site and switch M1 macrophages to M2 macrophages that induces fibrosis and inhibits satellite cell and myoblast proliferation and differentiation ${ }^{[22,30,33]}$. On the other hand, Garg et al. (2015) stated that dextrose prolotherapy inhibit transforming growth factor beta (TGF-beta) which switch macrophages from M1 to M2 that increase collagen deposition and induces fibrosis ${ }^{[22]}$.

In 28 day untreated muscle injury, Masson`s Trichrome stained sections revealed moderately packed collagen fibers surrounding newly formed muscle fibers together with densely packed ones, the area percentage of collagen deposition in this group revealed highly significant increase compared to control group. However, in 28 day treated group, Masson`s Trichrome stained sections revealed fine collagen inbetween muscle fibers which 
is similar to that of control group representing collagen remodeling, The area percentage of collagen deposition in this group revealed highly significant decrease compared to 28 day untreated group. This was reported by Mann et al. (2011) who stated that temporary extracellular matrix is formed as scaffold for new muscle fibers then undergoes degradation mediated by the expression of proteases and specific inhibitors released during tissue repair facilitating normal muscle healing ${ }^{[21]}$. On the other hand Rabago et al. (2010) reported that dextrose prolotherapy produce of less dense collagen type III that prevent the formation of normal dense collagen type I from being laid down ${ }^{[6]}$.

\section{CONFLICT OF INTERESTS}

There are no conflicts of interest.

\section{REFERENCES}

1. Tidball, J.G. (2011): Mechanisms of muscle injury, repair and regeneration. Compr Physiol; 1(4): 2029-2062.

2. Tsai, S.W.; Hsu, Y. J.; Lee, M. Ch.; Huang, H. E.; Huang, Ch. Ch. and Tung, Y. T. (2018): Effects of dextrose prolotherapy on contusion induced muscle injuries in mice. Int J Med Sci; vol.15(11): 1251-1259.

3. Baoge, L.; Van Den Steen, E.; Rimbaut, S. and Philips, N. et,al. (2012): Treatment of skeletal muscle injury: a review. International Scholarly Research Network Orthopedis; $\mathrm{p}: 1-7$.

4. Orchard, J.W.; Best, T.M. and Mueller-Wohlfahrt, H.W. et al. (2008): The early management of muscle strains in the elite athlete: best practice in a world with a limited evidence basis. Br J Sports Med; 42:158-159.

5. Meakins, A. (2012): Prolotherapy is it as sweet as it sounds. Thesports Physio; 11:20.

6. Rabago, D.; Slattengren, A. and Zgierska, A. (2010): Prolotherapy in primary care practice.Prim Care; 37(1): 65-80.

7. Campbell, R.S. and Dunn, A.J. (2012): Radiological interventions for soft tissue injuries in sport. $\mathrm{Br}$ J Radiol; 85(1016):1186-93.

8. Siadat, A.H. (2019): Prolotherapy: potential for the treatment of chronic wounds. Advances in Wound Care; 8(4): 160-167.

9. Hauser, R.A.; Lackner, J.B.; Steilen-Matias, D. and Harris, D.K. (2016): A systematic review of dextrose prolotherapy for chronic musculoskeletal pain. Clin Med. Insights Arthritis Musculoskeletal Disord; 9:139-159.

10. Kunduracioglu,B.;Ulkar,B.andSabuncuoglu,B.T.et,al. (2006): Effects of hypertonic dextrose on injured rat skeletal muscles.Neurosciences;11(2):93-96.

11. Takagi, R.; Fujita, N. and Arakawa, T. et,al. (2011): Influence of icing on muscle regeneration after crush injury to skeletal muscle in rats.J Appl Physiol;110:382-388.
12. Mishra, D.K.; Friden, J.; Schmitz, M.C. and Lieber,R.L. (1995): Anti-inflammatory medication after muscle injury: a treatment resulting in short term improvement but subsequent loss of muscle function.J Bone Joint Surg Am;77(10):1510-9.

13. Martins, C.A.Q.; Bertuzzi, R.T. and Tisot, R.A. et,al. (2012): Dextrose prolotherapy and corticosteroid injection into rat Achilles tendon.Knee Surg Sports Traumatol Arthrosc;20(10):1895-1900.

14. Drury, R.A.B. and Wallington, E.A. (1980): Carleton`s Histological Techniques. fifth edition Oxford University Press. New York; p.237.

15. Graham, L and Orenstein, J.M. (2007): processing tissue and cells for transmission electron microscopy in diagnostic pathology and research. Nature Protocols; 2(10): 2439-2450.

16. Somma, S.; Di Benedetto, M.P. and Salvatore, G. et al. (2004): Desmin- free cardiomyocytes and myocardial dysfunstion in end stage heart failure. European Journal of Heart Failure; 6(4): 389-398.

17. Sawilowsky S. (2005): Misconceptions leading to choosing the t-test over the Wilcoxon Mann-Whitney Test for Shift in Location Parameter. JMASM; (4): 598-600.

18. Ferreira Filho, C.M.; Santos Silva, A.M.D.; Machado, J.C.; Sudo, R.T. and Takiya, Ch.M. (2015): Laceration in rat gastrocnemius following up muscle repairing by ultrasound biomicroscopy in vivo, contractility test ex vivo and histopathology. Acta Cirurgica Brasileira;30(1): 1-11.

19. Youssef, M. F.; Zickri, M. B.; Gamal, M; Yassin, N.; Abd-Elal L. and El hadary, N. (2015): Effect of exercise training on induced skeletal muscle injury: a phsio-histological study. J Cytol Histol; 6:4.

20. Mehanna, R.A.; Soliman, G.Y.; Hassaan, P.S.; Sharara, G.M. and Abdel -Moneim, R.A. (2017): Protective role of melatonin on skeletal muscle injury in rats.Int J Clin Exp Med; 10(1): 1490-1501.

21. Mann, C.J.; Perdiguero, E.; kharraz, Y.; Aguilar, S. et al., (2011): aberrant repair and fibrosis development in skeletal muscle. Skeletal Muscle; $1(21): 1-20$

22. Garg, K.; Corona, B.T. and Walters, T.J. (2015): Therapeutic strategies for preventing skeletal muscle fibrosis after injury. Front Pharmacol; 6:87.

23. Lihua, H.E.; Guozhen, L.; Hongmei, Sh. and Xin, F. (2008): effect of energy compound on skeletal muscle strain injury and regeneration in rats. Industrial Health; 46(5): 506-12.

24. Winkler, T.; Roth, P.V. and Tohtz, S.V. (2011): Time course of skeletal muscle regeneration after severe trauma. Acta Orthop ; 82(1): 102-111. 
25. Lapointe, B.M.; Frenette, J. and Cote, C.H. (2002): Lengthening contraction induced inflammation is linked to secondary damage but devoid of neutrophil invasion. J Appl Physiol; 92:1995-2004.

26. Karalaki, M.; Fili, S.; Philippou, A. and Koutsilieris, M. (2009): Muscle regeneration: cellular and molecular events. In Vivo; 23:779-796.

27. Menetry, J.; Kasemkijiwattana, C.; Day, C.S. and Bosch, P. et al., (2000): Growth factors improve muscle healing in vivo. J Bone Joint Surg; 82-B: 131-7.

28. Anderson, A. (2015): The history of prolotherapy. Practical Pain Management; P.4.

29. Wang, Ch.; Yue, F. and Kuang, Sh. (2017): Muscle histology characterization using $\mathrm{Hx} \& \mathrm{E}$ staining and muscle fiber type classification using immunofluroscence staining. Bio Protoc; 7(10): e2279.

30. Prisk, V.R. and Huard, J. (2003): Muscle injuries and repair: the role of prostaglandins and inflammation. Histol Histopathol; 18: 1243-1256.

31. Novak, M.L.; Weinheimer-Haus, E.M. and Koh, T.J. (2014): Macrophage activation and skeletal muscle healing following traumatic injury. J Pathol; 232(3):344-355

32. Liu, X.; Zeng, Z.; Zhao, L.; Chen, P. and Xiao, W. (2019): Impaired skeletal muscle regeneration induced by macrophages depletion could be partly ameliorated by MGF injection. Frontiers in Physiology; vol.10:601

33. Kaariainen, M.; Jarvinen, T.; Jarvinen, M.; Rantanen, J. and kalimo, H. (2000): Relation between myofibers and connective tissue during muscle injury repair. Scand J Med Sci Sports; 10:332-337. 
الملخص العربى

\section{دراسة هستولوجية عن تأثير الدكستروز برولوثيرابي علي اصابة العضلات الهيكلية في ذكور الجرذان البيضاء البالغة}

إيمان ضياء الدين سلامة، عزه صلاح الدين سليمان، رانيا أحمد صلاح الدين، جورج فايق برسوم حنا، قسم التشريح و الاجنه ــ كليه الطب ـ جامعة عين شمس

الخلفية: تمثل اصابات العضلات الهيكلية واحدة من الاصابات الأكثر شيوعا في الطب الرياضي، فهي تتر اوح بين

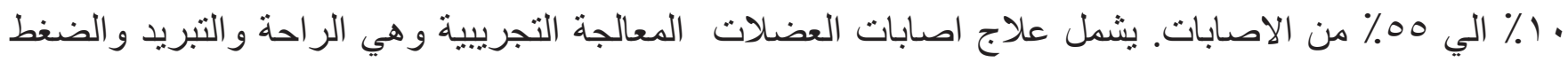

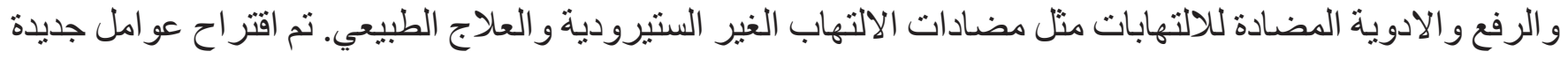

$$
\text { لعلاج الاصبابات العضلية كالعلاج التكاثري (البرولوثير ابي). }
$$

تعمل محاليل الد كستروز عن طريق تجفيف الخلايا في موقع الحقن لانتاج صدمة للانسجة التي بدور هاتحفيز الحفز الدورة الالتهابية عن طريق جذب الخلايا الالتهابية والبلاعم إلى الموقع المصاب كما أنها تطلق العديد من عو امل النمو كعامل

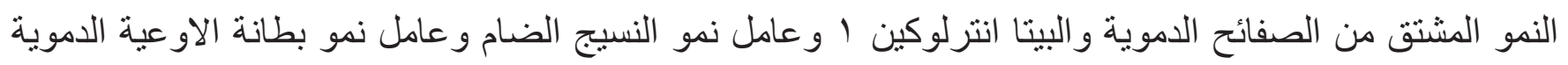
وعو امل نمو الانسولين التي تساعد في عملية الثفاء. الهُف من العمل: كان الهدف من هذا العمل هو تقييم التأثير النسيجي و التشكيلي للتأثير العلاجي المحتمل لحقن علاج الدكستروز كعلاج جديد للثفاء من إصابة العضلات من هنات الهيكلية. المواد والطرق المستخدمة: في هذة الدر اسة تم استخدام ثلاثه وستون من ذكر الجرذان البيضاء البـاء البالغة و التي قسمت إلى ثناث مجمو عات.

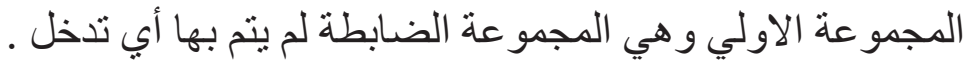

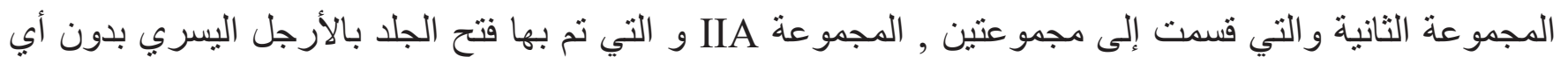
إصابة بالعضلة الخلفية ثم خياطة الجرح و المجموعة IIB و التي تم بها فتح الجلد بالأرجل اليمني و عمل جرح عرضي بالعضلة الخلفية ثم خياطة الجرح. المجموعة الثالثة و التي قسمت الي مجمو عتين، المجموعة IIIA (المجموعة المحقونة بالليدوكين) و التي تم بها حقن الارجل اليسري ب ب, • مل من 1\% لبدوكين فقد تم اعطاء الجرذان ستة جر عات من الليدوكين مع فاصل خمسة ايام

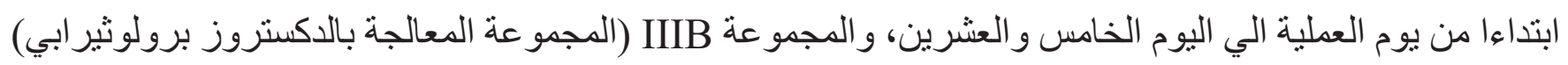

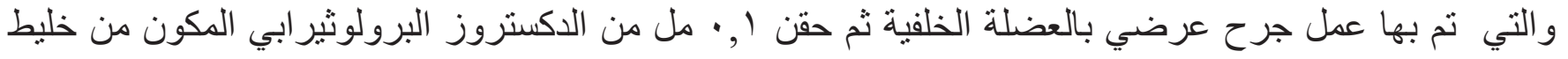

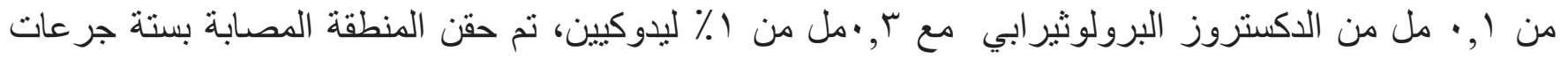

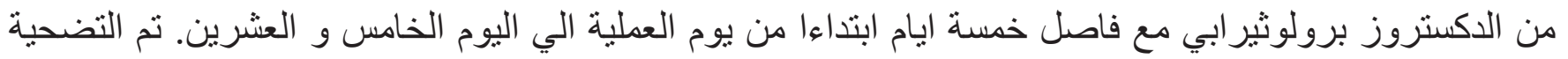

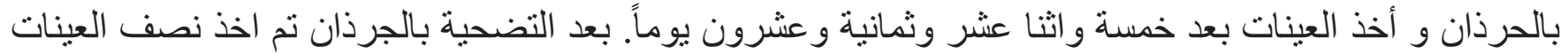

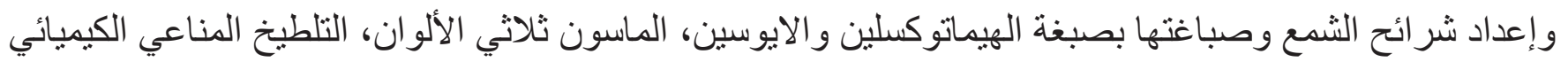

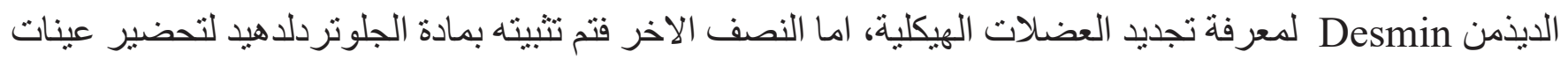


التولويدين بلو، بعد ذلك تم فحص جميع الثُر أنح المصبو غة بالميكرسكوب الضوني اولمبس و نصوير ها.

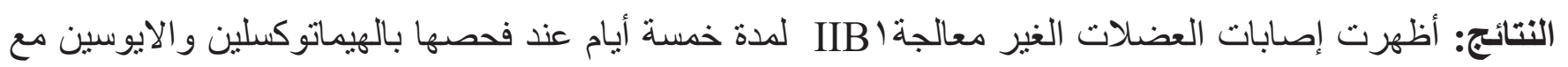

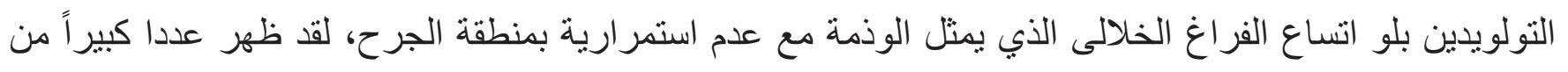

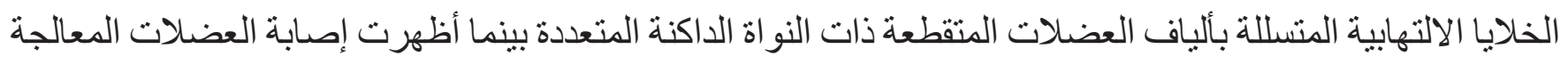

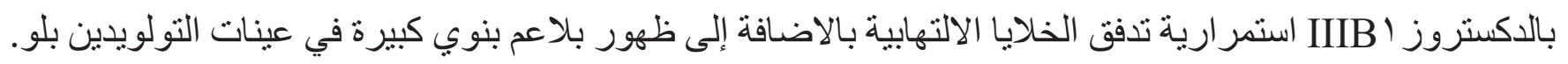
علاوة علي ذللك اتضح في الإصابة الغير معالجة لمدة اثنا عشر يوما IIB عند فحصها بالهيماتوكسلين والايوسين

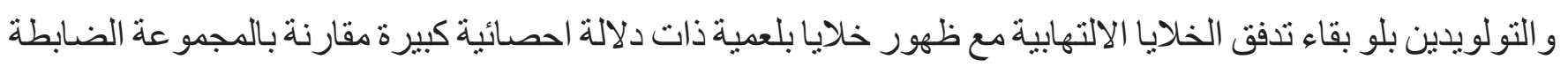

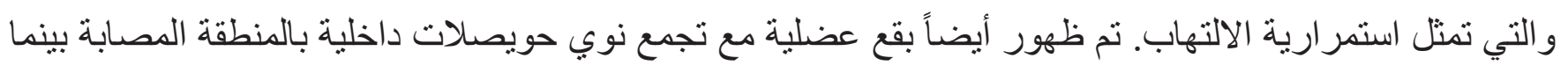

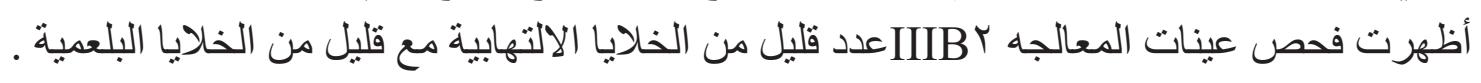

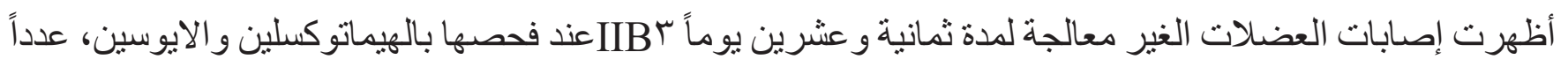

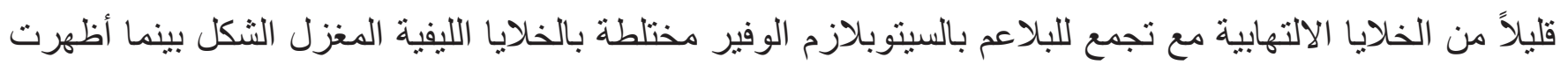

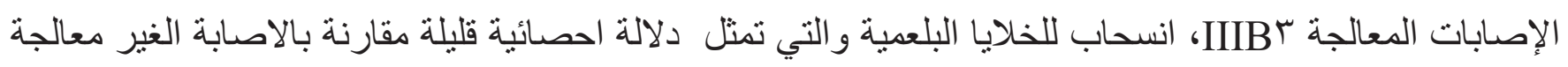

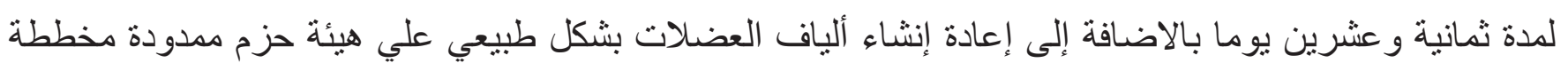
اسطو انية مرتبة بنمط متو ازي مع نوي مسطحة مستو بالانية محيطيا.

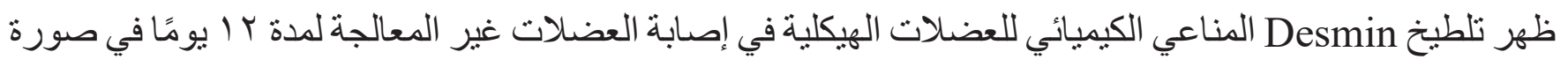

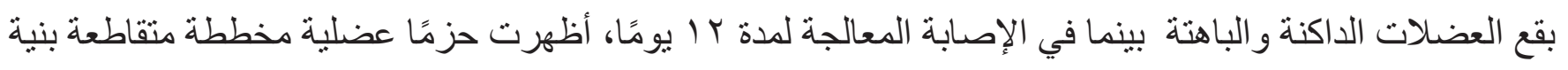

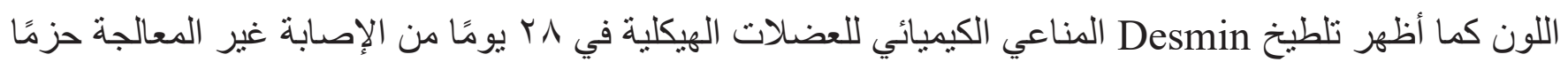

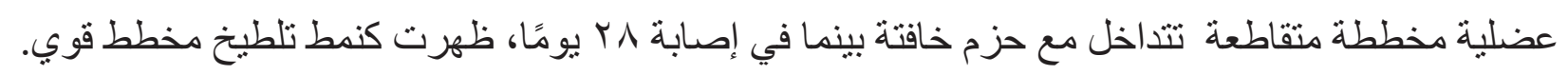
الاستتتاج: كان علاج الدكستروز فعالاً في التئام الأنسجة الرخوة حيث أدى إلى تسريع تكاثر وتمايز الخلايا العضلية. 